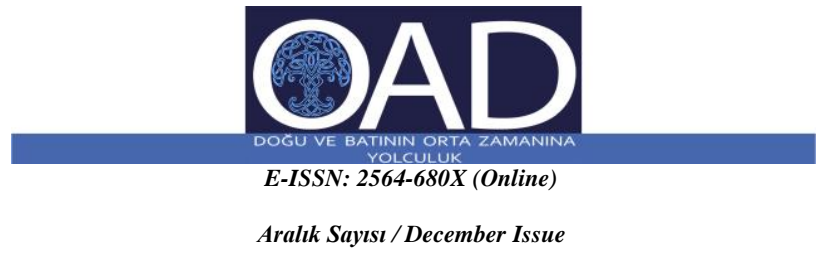

Yıl 3, Sayı 2 / Year 3, Issue 2

ATIF BILLGISI / REFERENCE INFORMATION

ATAK, Erkan, “Taşa İşlenen Zarafet Lâle: Cami Tezyinatında Kullanımı Üzerine Bir Değerlendirme (14-18. Yüzyıllar)” Ortaçağ Araştırmaları Dergisi, III/II, Aralık 2020, s. 226-239.

Makale Türü: Sanat Tarihi Araştırma Makalesi

DOI No: https://doi.org/10.48120/oad.821928

Geliş Tarihi / Received: 05 Kasım 2020

Online Yayın: 26 Aralık 2020

Kabul Tarihi / Accepted: 24 Kasım 2020

Published Online: 26 December 2020

\title{
Taşa İşlenen Zarâfet Lâle: Cami Tezyînâtında Kullanımı Üzerine Bir Değerlendirme (14-18. Yüzyıllar) Erkan $\operatorname{ATAK}^{1^{*+}}$
}

\author{
${ }^{1}$ Doç. Dr., Sakarya Üniversitesi, Fen-Edebiyat Fakültesi, Sanat Tarihi Bölümü, SAKARYA. \\ *erkanatak@sakarya.edu.tr \\ ${ }^{+}$ORCID: 0000-0002-8977-8999
}

$\ddot{\boldsymbol{O}} \boldsymbol{z}$ - Türk kültüründe çiçeklere duyulan sevginin İslâmiyet öncesi dönemlerden başlayarak günümüze değin hiç kesintiye uğramadan hatta üzerine koyarak ulaştığ1 görülür. Özellikle 16. yüzyıldan itibaren bu ilginin sadece çiçek merak1 ve sevgisinin ötesine geçip başta sanat dalları olmak üzere birçok alanda somutlaşması, günümüze yüklü bir mirasın ulaşmasına vesile olmuştur. Farklı cinsten birçok çiçeğin bu sevgiden payını aldığı muhakkaktır. Ancak bunların arasında lâlenin ayrıcalıklı bir yerinin olduğunu söylemek gerekir. Roma ve Bizans dönemlerinde bilinmeyen lâlenin Anadolu'ya 12. yüzyılda Türklerle beraber girdiği kabul edilir. Türklerin Anadolu öncesindeki kadim kültürlerinin bir parçası olan lâle, bu coğrafyada yaygınlaşmış, sanattan edebiyata birçok alanda vazgeçilmez motiflerden birisi haline gelmiştir.

Lâlenin yaygın olarak kullanıldığı alanlardan birisi mimari süslemedir. Lâle Devri'nde çeşme ve sebiller başta olmak üzere sivil eserlerin taş tezyînâtında yaygın bir biçimde kullanılan lâle, camilerinin taş süslemelerinde ne düzeyde yer almıştır. Makalemiz bu sorunun cevabına yönelik ele alınmıştır. Lâle motifinin camilerin taş süslemesinde kullanımını kronolojik bir düzenle verilmiş böylelikle, 18. yüzyıl camilerinin taş tezyînâtında yaygın olarak karşılaşılan lâle motifinin önceki yüzyıllarda kullanım oranı ortaya koyulmaya çalışılmıştır.

Anahtar Kelimeler- Lâle, camii, süsleme, 18. Yüzyıl, Osmanlı Devleti.

\section{The Tulip, Elagance in Stone: An Evaluation on Its Usage on Mosque Decoration (14-18. Centuries)}

\begin{abstract}
It is observed that the love for flowers in Turkish culture has reached until today, with no interruption, even increasing, starting from pre-Islamic times until today. In particular, the fact that this interest has been embodied in many fields mainly in the branches of art beyond only the curiosity and love of flowers since the 16th century has been instrumental in causing that an extensive legacy has reached today. It is certain that many flowers of different species take their share from this love. However, it must be said that tulip has a special place among them. It is accepted that the tulip, which was not known in the Roman and Byzantine periods, entered Anatolia in the 12th century together with the Turks. Tulip, which is a part of the ancient culture of Turks before Anatolia, has become widespread in this geography and an indispensable pattern in many fields, from art to literature.

Architectural decoration is one of the areas where tulip is widely used. Tulip was widely used in the stone decoration of civil works in the Tulip Period. On the other hand, to what extent this motive was used in the stone decoration of mosques. Our article deals with the answer to this question. The use of tulip motive in stone decoration of mosques is given in a chronological order. Thus, the usage rate of tulip motive, which was widely used in the stone decoration of 18 th century mosques, in previous centuries was tried to be revealed.
\end{abstract}

Keywords - Tulip, mosque, decoration, 18th Century, Ottoman Empire. 


\section{Giriş}

Türklerin çiçek sevgisi İslamiyet öncesi dönemlere dayanır. Erken devir Türk sanatında farklı türden çiçek tasvirleriyle karşılaşabilmek mümkündür. Orta Asya bozkırlarında yetișen çiçeklerden birisi olan lâle, Türklerin kültür ve sanatında yaygın olarak yer bulmuş çiçeklerden birisi olarak karşımıza çıkmaktadır. Hun döneminde 5. Pazırık Kurganı'ndan çıkarılmış keçe üzerine aplike işlenen duvar örtüsünde tahta oturmuş bir tanrıça ve karşısında atlı bir figür yer alır. Tanrıçanın elindeki hayat ağacının uçlarında lâle motifleri göze çarpmaktadır. ${ }^{1}$ Uygur devri Bezeklik tapınaklarından 9 numaralı tapınağa ait bir freskte tasvir edilen Uygur prensi elinde zarif bir lâle tutmaktadır. Günümüzde Berlin Staathiche Museen'de yer alan duvar resmi 8.-9. yüzyıllara tarihlendirilir. ${ }^{2}$ Yine aynı tapınağa ait olan Uygur asilleri (prensesleri) ve rahiplerini tasvir eden bir başka duvar resminde ise prensesin elinde benzer zarif bir lâle çiçeği bulunur. ${ }^{3}$ Uygur devri Koça Alfa Tapınağı'nda bulunan 9. yüzyıla ait bir varakta ise diz çökmüş vaziyette yan yana oturan iki figürün altında gonca halinde iki çiçek motifi görülür. Yeşil saplardan çıkan üç parçalı mor ve kırmızı çiçekler form itibariyle lâle motifine benzemektedir. ${ }^{4}$ Yukarıdaki örnekler lâlenin İslâmiyet öncesi Türk devletlerinde tanınan bir çiçek olduğunu ortaya koymaktadır.

Lâlenin ana vatanı Orta Asya'dır. Buna karşın Anadolu'dan Kafkasya'ya, Avrupa'dan Amerika kıtasına kadar çok geniş bir coğrafyada görülebilmektedir. ${ }^{5}$ Doğal haliyle birçok farklı rengi bulunan bu zarif çiçeğin isminin Türkçe "tülbent" sözcügünden türetildiği ve İngilizce'ye “Türk takkesi” (Turk'scap) olarak geçtiğ ifade edilmektedir. ${ }^{6}$ Osmanlı dönemi çiçek risâlelerinde lâlenin yetiştirilme yöntemleri üzerine bilgiler bulunmaktadır. ${ }^{7}$ Söz konusu bilgilerde göze çarpan hususlardan birisi lâlenin çok sıcak ve nemli ortamları sevmediğidir. $\mathrm{Bu}$ da Orta Asya bozkırlarının lâlenin yetişebilmesi için elverişli olduğunu göstermektedir. Zamanla 1slah edilmeye başlayan ve geniș bir coğrafyaya yayılan lâle çiçeği bazı toplumların kültürleri ve sanat anlayışları üzerinde etkili bir motif haline gelmiştir. Bunlardan birisi ve hatta en önemlisi Türk toplumudur. Lâle çiçeği tarih içerisinde Türk kültürü ve sanatı üzerinde o kadar etkili hale gelmiştir ki kimi zaman bir döneme ismini vermiş kimi zaman bir sanat anlayışının şekillenmesinde temel motiflerden birisi olmuştur. ${ }^{8}$ Lâlenin Anadolu'da Türkler'den önce Roma ve Bizans dönemlerinde bilinmediği görülür. Yani bu çiçek Türkler'in Orta Asya, İran ve Türkistan bölgesinde şekillenen kadim kültürlerin bir parçası olarak 12. yüzyılda Anadolu'ya taşınmıştır. Bu tarihten sonra lâle, toplumun sosyal yaşamında, kültüründe ve sanat anlayışı içerisinde gün geçtikçe tesirini arttırmış ve mimariden edebiyata, küçük el sanatlarından bahçe düzenlemelerine, kumaştan halıya, yazma kitaplardan çinilere kadar birçok alanda kullanılmıştır. Kimi zaman bu çiçeğe olan ilgi sadece Türkler'de değil birçok ülkede "lâle çılgınlığı" (tulipomania) denilen aşırı boyutlara ulaşmıștır." Lâlenin zarif yapılı bir çiçek olması, baharı müjdeleyen rengârenk renklerle ovaları ve bahçeleri kaplaması, hoş kokusuyla insanda mutluluk ve sevinç duyguları uyandırması, motif olarak işlendiği her alana ayrı bir güzellik katması, zarâfetiyle şair ve sanatçılara ilham kaynağı olması gibi sebepler bu ilginin nedenini açıklayabilir. Çoğunlukla bir ay gibi ömrü olan, güneşte hemen solabilen narin bir çiçek olan lâlenin bu hassas yapısı özellikle şairlerin şiirlerinde kullandıkları bir malzeme olmuştur. Mevlâna Celaleddin Rumî'nin ilk olarak mısralarına ${ }^{10}$ taşıdığ lâleyi sonraki yüzyıllarda Şeyhî ${ }^{11}$, Necâtî ve Bakî ${ }^{12}$ gibi birçok şairin sıklıkla kullandıkları görülmektedir. ${ }^{13}$ 18. yüzyılın başlarında ise Nedîm $^{14}$ ve Seyyid Vehbî ${ }^{15}$ 'nin şiirlerinin vazgeçilmez unsurlarından birisidir. Türk şiirinde farklı lâle türlerinin isimlerine ve renklerine sıklıkla yer verilmiștir. Lâle, kimi zaman sevgiliye duyulan duyguları anlatır, kimi zaman aşkı tarif eder kimi zaman da bahar coşkusunu yansıtır. ${ }^{16}$ 3. Ahmed ve Nevşehirli Damad İbrahim Paşa ile özdeşleşen ve
${ }^{1}$ Nejat Diyarbekirli, Hun Sanatı, Milli Eğitim Bakanlığı Kültür Yayınları, İstanbul, 1972, s. 136.

${ }^{2}$ Yaşar Coruhlu, Erken Devir Türk Sanatı, Kabalcı Yayınevi, İstanbul, 2007, s.269-271.

${ }^{3}$ Bahaeddin Ögel, İslamiyetten Önce Türk Kültür Tarihi Orta Asya Kaynak ve Buluntularına Göre, Türk Tarih Kurumu Yayınları, Ankara, 1984, s. 351-357

${ }^{4}$ Şehnaz Biçer Özcan, Uygur Yazmalarında Sayfa Düzeni, Basılmamıs Doktora Tezi, Marmara Üniveristesi Türkiyat Araştırmaları Enstitüsü, 2010, s.177-183.

${ }^{5}$ Münir Aktepe, "Damad İbrâhim Paşa Devrinde Lâle", Tarih Dergisi 7, 1953 s. 85-126.; Feyzullah Dayıgil, "İstanbul Çinilerine Lâle", Vakıflar Dergisi 2 , 1942, s. 223-232.; Alev Çakmakoğlu Kuru, "Orta Asya Türk Sanatında Palmet ve Lâle Motiflerinin Değerlendirmesi Hakkında Bir Deneme". Belleten 230, 1997, s. 37-54.

${ }^{6}$ Jack Goody, Çiçeklerin Kültürü, (Çev. Mehmet Beşikçi), Ayrıntı Yayınları, İstanbul, 2010, s. 271.

${ }^{7}$ III. Ahmed devrinde baş çiçekci (ser şûküfeci) Lâlezarî Mehmed Efendi’nin Mîzânü'l-ezhâr'ında lâlelerin yetiștirilme yöntemlerinden bahsederken lâle toprağına dikkat edilmesi gerektiği, killi, yağlı veyahut etli topraklarda soğanların yetişemeyeceği, bu suretle de yarısı kadarının et toprak ve diğer yarısının da ufak taş ile kumlu olan toprakların makbul olduğunu ifade eder. Lâle soğanının hararet ve yubuset (sıcaklık ve kuruluk) ayarının, ekim zamanının, soğan cinslerinin, hava şartlarının ve su miktarının hassas bir biçimde ayarlanması gerekliliği üzerine bilgiler verir. Bkz. Seyit Al Kahraman, Osmanlı Çiçekleri ve Çiçekçileri, Lale Yayınları, İstanbul, 2014, s.95-103.

${ }^{8}$ Lâlenin Türk kültürü ve sanatındaki yeri “Orta Asya'dan Anadolu'ya Lâle Çiçeğinin Türk Kültürü ve Sanatındaki Yeri ( Importance of Tulip Flower in Turkish Culture Ans Art From Central Asia To Anatolia)" adlı başka bir çalışmada (basım aşamasında) ele alındığından makalede, bu bağlamdaki bilgilere detaya girilmeden giriş mahiyetinde değinilmiştir.

${ }^{9}$ Turhan Baytop ve Cemal Kurnaz, "Lâle", İslam Ansiklopedisi. C.27, Türkiye Diyanet Vakfi Yayınları, Ankara, 2003, s. 79-81.

${ }^{10}$ Mevlâna Celâleddin Rûmî Dîvân-1 Kebîri'nde lâleye dair bir çok mısra kaleme almıştır. Örneğin: Selviden mi söz açayım, lâleyi mi söyliyeyim, yoksa yaseminden mi bahsedeyim?...Lâle kanla ylkansın, nerkis hasretle bakakalsın, gonce başından külâhını atsın, süsen, süsenlig̈inden geçsin...O gönüller alan lâle yüzlü güzelimin yüzünden benzim safrana dönmede; neseme nese katan o güzelin yüzünden her an işim gücüm artıp durmada...Nerde süsen, nerde ağustos gülü, nerde selviliklerin lâleleri, nerde yasemin?...Ne başı dönmüs selviye dönerdim, ne oynayıp duran sümbüle; ne lâ l lelbiseli lâle kesilirdim ne sapsarı safran...Ey lâle gibi kzzl yüzünden safran gibi sararmış yüzümüz; ey derdiyle, saçlarındaki tarak gibi gamları batmış gönül...Nihayet gonca açıllı da süsenin sırrın söyler selviye, lâle söğ̈̈t ağacıyla erguvana müjdeler verir...Tebrizli Şems'in civarına kaçıp vardığın zaman Allah bilir, orda ne çeşit bir lâleliğe girersin. Bkz. Abdülbâki Gölpınarlı, Mevlânâ Celâleddin Dîvân-ı Kebîr, Remzi Kitapevi, İstanbul, 1957.

${ }^{11}$ Şeyhî lâleye şiirlerinde çok defa kullanan şairlerdendir. Divanında örneğin: "Gül meclisinde cümlesi ser-mest ü mey-perest, Her lâle bir piyâlevü her bir semen şahem"... "Gamzesinden nergisün akl u gönül hayrân u mest, Şûrişinden lâlenün cân u ciğerler kan ola." Bkz. Şeyhî Dîvânı, (Haz. Halit Biltekin), Kültür ve Turizm Bakanlığ̆ Kültür Eserleri, Ankara, 2018.

${ }^{12}$ 16. yüzyılın meşhur şairlerinden Bâkî divanında lâleye yaygın olarak yer veren şairler arasındadır. Mesela: "Gül meclisinde lâle yine kildı âşikâr, Aŷini bezm-i işret-i Cemşîd-i kâmkâr"... "Pîrehen berg-i semen gûy-i girîbân şebnem, Gülsitân old bu gün bir sanem-i lâle-izâr"... "Lâlelerle bezene niteki dest ü sahrâ, Nitekim güller ile zevn ola dest ü destâr " Bkz. Bâki Dîvânı, (Haz. Sabahattin Küçük), Ankara: Kültür ve Turizm Bakanlı̆̆ı Kültür Eserleri, ty. ${ }^{13}$ Süheyl Ünver, "Türkiye"'de Lâle Tarihi," Vakıflar Dergisi, 9, 1974, s. 265276

${ }^{14}$ Lâlenin Türk edebiyatındaki tartışmasız yeri XVIII. yüzyılda adeta zirveye ulaşmıștır. Dönemin ünlü şairlerinden Nedim'in şiirlerinde gerek lâleye gerekse ismini verdiği Lâle Devri'nin sosyal yapısına atıfta bulunulan mısralara siklıkla yer verilmiştir. Mesela: "Vardır ol bâğda bir neş'e-i câvîdmeğer, Lâlenin tohmunu eksen dolu peymâne gelir"... "Lâle-zâr' 'n da acâyibşevkl var hasrettedir, Ol da yüz sürmek diler Hünkârımın dâmâdına".. "Hos geldin eyâbâis-i ârâyiș-i âlem, Ey lûtf-u kerem gülșeninin lâle zamânı"... "Lâleyi bir iki gün anmayalım şimdi hele, Kâmlar sohbet-i helvâ ile olsun șîrîn" Bkz. Nedim Divanı, (Haz. Abdülbâki Gölpınarlı), İnkilâp Kitabevi, İstanbul, 1951.

${ }^{15}$ Seyyid Vehbi divanında lâlenin dönemin ortamına uygun olarak yansıdığı görülür. Mesela: "Bir șise ttr-l șâhi olur her kadehleri, Bir lâlezârahulkı ki bâd-ı vezân olur"... "Lâle zemânirûy-i zemin âsumân olur, Necmsitâre-i pertev-i Enver-feşân olur" Bkz. Hamit Dikmen, Seyyid Vehbi ve Divanının Karşılaştırmalı Metni, Basılmamış Doktora Tezi, Ankara Üniversitesi Sosyal Bilimler Enstitüsü, 1991.

${ }^{16}$ Ahmet Kartal, Klâsik Şiirinde Lâle, Akçağ Yayınları, Ankara,1998, s. 1389. 
sonraları "Lâle Devri" 17 ismiyle meşhur olan yıllarda ise lâleye olan ilginin zirve yaptığı görülmektedir. Bu dönemde lâle sevgisi öyle bir hâl almıştır ki şairlerin şiirlerinin, ressamların resimlerinin, ustaların binalarının merkezinde bu çiçek karşımıza çıkmaktadır.

Lâle, mimari süslemede ve kitap sanatlarında 18. yüzyılın başından itibaren toplumda gördüğü ilgiye paralel olarak yaygınlık kazansa da Osmanlı sanatında kullanımı erken dönemlere kadar uzanmaktadır. ${ }^{18}$ Erken ve klasik dönemlerde daha çok çini ve kalem işi süslemelerde karşımıza çıkmaktadır. Klasik dönem kalem işi süslemelerde yarı stilize bir düzenle nakşedilen lâlenin aynı dönemin çini süslemelerinin en çok kullanılan motiflerinden olduğu görülmektedir. Özellikle Mimar Sinan ve sonrasında inşa edilen yapıların süslemelerinde yer alan İznik çinilerinin belirleyici motiflerinden olan lâlelerin, Rüstem Paşa Camii (1561), Sokullu Mehmed Paşa Camii (1572), Sultan Ahmed Camii (1609-1620) ve Yeni Camii (1663) gibi 16. ve 17. yüzyıllarda inşa edilmiş birçok mimari eserde farklı türden çiçeklerle birlikte tasvir edildiği görülmektedir (Fotoğraf 1). ${ }^{19}$ Lâle, kitap sanatlarında ise çini ve kalem işi süslemelere nazaran daha natüralist bir üslupla işlenmiştir. 16. yüzyılın ikinci yarısı örnekleri arasında yer alan Kanuni Divanı'nın iki nüshasında ${ }^{20}$ ve Matrakçı Nasuh'un 1537 tarihli "Mecmu'-i Menâzil" adlı eserinde ${ }^{21}$ natüralist ve stilize çiçekler arasında lâle motifleri yer almaktadır. 17. Yüzyıl kitap sanatlarında kullanılmaya devam eden lâle motifi yüzyılın ikinci yarısından itibaren mimari süslemede daha natüralist olarak tasvir edilmeye başlanmıştır.

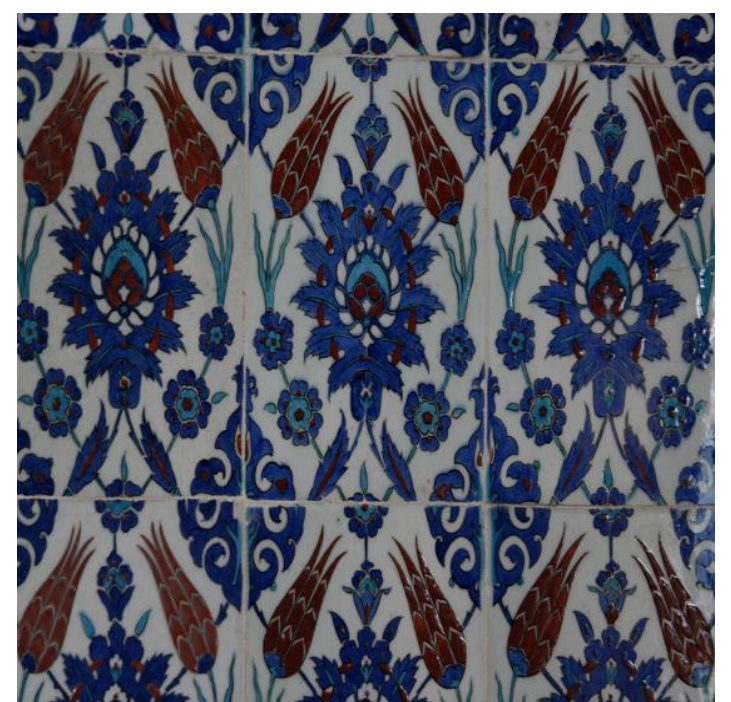

Fotoğraf 1: Rüstem Paşa Camii çinilerinde lâle motifi detayı $^{22}$

17 Yılmaz Öztuna, "Lâle Devri" isminin simgesi olan lâleden dolayı ilk önce Yahya Kemal Beyatlı tarafindan önerildiği daha sonra Ahmed Refik Altınay'ın bu dönemi konu alan eseriyle "Lâle Devri” ismini yaygınlaştırdığ görüşündedir. Bkz. Yılmaz Öztuna, Başlangıcından Zamanımıza Kadar Büyük Türkiye Tarihi, 5, Ötügen Yayınları, İstanbul, 1978, s. 289. Ahmed Refik Altınay kitabında dönemin sosyal yaşantısını ve siyasi olaylarını hikâye üslûbunda aktarmaktadır. Bkz. Ahmed Refik Altınay, Lâle Devri, Tarih Vakfı Yurt Yayınları, İstanbul, 2011.

${ }^{18}$ Lâle motifinin kimi zaman tespitinde güçlükler yaşanmaktadır. Özellikle palmetle benzerliği iki motifin bazen karıştırılmasına sebep olmaktadır. Bkz. Yıldız Demiriz, Osmanlı Mimarisinde Süsleme (İstanbul: Kültür Bakanlığ Publications, 1979), 27. Palmet motifi için çok farklı tipler tanımlanmasına karşın, düşey bir eksenin iki yanında, simetrik olarak yer alan parçalardan müteșekkil bir ana tip saptayabilmek mümkündür. Bkz. Selçuk Mülayim, "Selçuklu Palmet Motiflerinin Tipolojisi," Anadolu (Anatolia), 20,1976, s. 141-153. Bu hususta palmet ve lâle motiflerini oluşturan parçalardan dağılım aşağı doğru yönelmiş olanları palmet, dağılımları yukarı toplanmış üç parçalı motiflerin büyük bir kısmını ise lâle olarak değerlendirmenin mümkün olabileceğine dair öneriler mevcuttur. Bkz. Çakmakoğlu, "Orta Asya...", s. 41.
Lâle Devri ve sonrasinda ise vazolu buketlerin temel motiflerinden birisi olmuş ve gerek mimari süslemede gerekse kitap sanatlarında sevilerek kullanılmıştır. Bu yüzyıldaki yazma örneklerinde zaman zaman aşırıya varan dar ve uzun formlu lâleler dikkati çekmektedir. Özellikle Ali Üsküdârî ve Abdullah Buhârî gibi dönemin önde gelen nakkaşlarının eserlerinde ince uzun formlu lâleler çiçek buketleri arasında tasvir edilmiştir. ${ }^{23}$ Mimari süslemede ise camilerin, kütüphanelerin, köşk ve kasırların duvarlarında ve tavanlarını süsleyen natüralist kompozisyonların merkezinde lâle motifi yer almaktadır. Toplumda lâle çiçeğine olan sevginin artmasınla paralel olarak gelişen bu sanat anlayışı, 18. yüzyılın ilk yarısında başta İstanbul olmak üzere Anadolu'nun çeşitli merkezlerinde inşa edilen eserlerin alç1, sıva veyahut ahşap üzerine kalem işi süslemelerinde kendini gösterir. Amcazade Hüseyin Paşa Yalısı Divanhânesi (1700), 3. Ahmed Yemiş Odası (1705), 3. Ahmed Kütüphanesi (1719), Mudanya Tahir Paşa Konağı (1724) ve Nevşehir Damat İbrahim Paşa Kütüphanesi (1727) gibi sivil yapılardaki kalem işi süslemelerde dönemin üslubuna uygun ince-uzun formlu lâlelerden müteşekkil vazolu kompozisyonlar görülür (Fotoğraf 2). ${ }^{24}$ Bunların dışında Lâle Devri'nde Tekfur sarayında üretilen çinilerde de lâle motifine yer verildiği görülmektedir. ${ }^{25}$ Ancak bu çinilerdeki lâle motifleri klasik dönem üslubundan farklı olarak daha natüralist ele alınmış ve dönemin sevilen lâle çeşitleri gibi ince uzun gövdeli formlarda tasvir edilmişlerdir. Lâle Devri'nin hemen sonrasında inşa edilen Hekimoğlu Ali Paşa Camii (1734) çini süslemelerinde dönemin çiçek risalelerinde isimleri geçen ve rağbet gören Gül-reng-i feyz, Ferahengîz, Turuncu Şeyhî ve Mir'ât-i sabâh ${ }^{26}$ gibi lâle çeşitlerinden ilham alındığı görülmektedir.

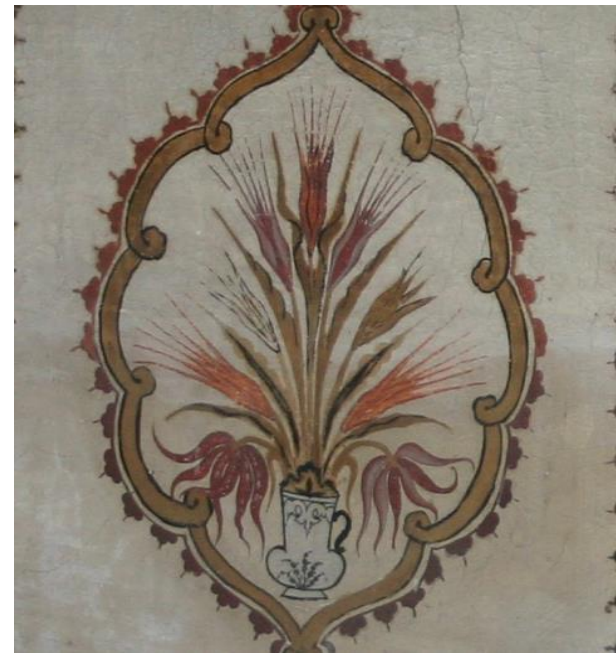

Fotoğraf 2: Nevşehir Damad İbrahim Paşa Kütüphanesi Kalemişi Süsleme

${ }^{19}$ Feyzullah Dayıgil, "İstanbul Çinilerinde Lâle”, Vakıflar Dergisi 1, 1938, s. 83-90.; Dayıil, "İstanbul Cinilerinde...", s. 223-232.

${ }^{20}$ Yıldız Demiriz, Osmanll Kitap Sanatında Natüralist Üslûpta Çiçekler, İstanbul Üniversitesi Edebiyat Fakültesi Yayınları, İstanbul, 1986, s.355-356. ${ }^{21}$ Serpil Bağcı, Filiz Çağman, Günsel Renda, Zeren Tanındı, Osmanlı Resim Sanatı, Kültür ve Turizm

Bakanlığı Yayınları, İstanbul, 2006, s.77, resim no: 46

${ }^{22}$ http://www.mustafacambaz.com/details.php?image $\mathrm{id}=12844$ erişim tarihi: 04.11 .2020

${ }^{23}$ Y1ldı Demiriz, Osmanlı Kitap Sanatında..., s.356.

${ }^{24}$ Bkz. Erkan Atak, "Osmanlı Mimarisinde Lâle Devri Üslûbu (Anadolu'daki Yansımalar)" Turkish Studies, Vol.13/10, 2018, s.57-86.; Zekiye Uysal, “Topkapı Sarayındaki III. Ahmet Kütüphanesi'nin Alçı Süslemeleri”, Canakkale Araștırmaları Türk Yıllı̆̆ , Sayı: 26, 2019, s. 331-376.

${ }^{25}$ Filiz Yenişehirlioğlu, "Tekfur Sarayı Çinileri ve Eyüp Çömlekçiliği”, Anadolu'da Türk Devri Cini ve Seramik Sanatı, (Ed. Gönül Öney, Zehra Çobanlı), Kültür ve Turizm Bakanlığı Yayınları, İstanbul, 2007, s.349-364.

${ }^{26}$ Ekrem Hakkı Ayverdi, 18. Asırda Lâle. (Haz. M. Uğur Derman), Kubbealtı Neșriyâtı, İstanbul, 2006, s. 18-66. 
Gerek erken ve klasik dönemde gerekse Lâle Devri ve sonrasında farklı türden yapıların kalem işi ve çini süslemelerinde yaygın olarak yer alan lâlenin, taş süslemede kullanımının 18. yüzyıldan itibaren arttığ1 görülmektedir. Özellikle dönemin sivil yapılarında lâle motifinin en zarif örnekleri karşımıza çıkar. Lâle Devri çeşmelerinin süslemesinde bu çiçeğin kullanımı adeta bir moda haline gelmiştir. Üsküdar Yeni Valide Çeşmesi (1710), Topkapı ve Üsküdar 3. Ahmed çeşmeleri (1728), Tophane Çeşmesi (1732), Bereketzade Çeșmesi (1732), Azapkapı Saliha Sultan Çeşmesi (1732), Hekimoğlu Ali Paşa Çeşmesi (1732) ve Bolvadin Ağılönü Çeşmesi (1748) gibi Lâle Devri'nde ve hemen sonrasında inşa edilen çeșmelerin süslemelerinde en çok tercih edilen motiflerin başında lâle gelmektedir (Fotoğraf 3-4). ${ }^{27}$ Söz konusu süslemelerin bazılarında lâleli vazolar sehpalar üzerine oturtularak aynı dönemin resim sanatında olduğu gibi perspektif ve mekân arayışlarına gidilmiştir. Başkentin çehresini kısa bir sürede etkileyen bu üslubun Lâle Devri sonrasında daha olgun bir biçimde devam ettirildiği görülür. 18 yüzyılın ortalarından itibaren bu durum sadece İstanbul'la sınırlı kalmamış Anadolu'nun farklı yörelerine de tesir etmiştir. Çeşme ve sebiller başta olmak üzere sivil eserlerin taş tezyînâtında bu denli yaygın bir biçimde kullanılan lâle, camilerin taş süslemelerinde ne düzeyde yer almıştır? Makalemiz bu sorunun cevabına yönelik ele alınmıştır. Lâle motifinin taş süslemede kullanımının kronolojik bir düzenle verilebilmesi amacıyla metin içerisinde yapılar 18. yüzyıl öncesi ve 18. yüzyıl olmak üzere iki başlık altında toplanmıştır. Böylelikle, 18. yüzyıl camilerinin taş tezyînâtında yaygın olarak karşılaşılan lâle motifinin önceki yüzyıllarda kullanım oranı ortaya koyulmaya çalışılmıştır. Her bir yapı için ayrı başlıklar açmak yerine paragraflar şeklinde bir düzen izlenerek metin içerisinde bir bütünlük sağlanmasına gayret edilmiştir. Yapılar yer aldıkları paragraflar içerisinde değerlendirilmiş ve benzer örneklerle karşılaştırılmıştır. $\mathrm{Bu}$ suretle tekrardan kaçınmak maksadıyla ayrıca bir değerlendirme başlığı açılmasına gerek duyulmamıştır.

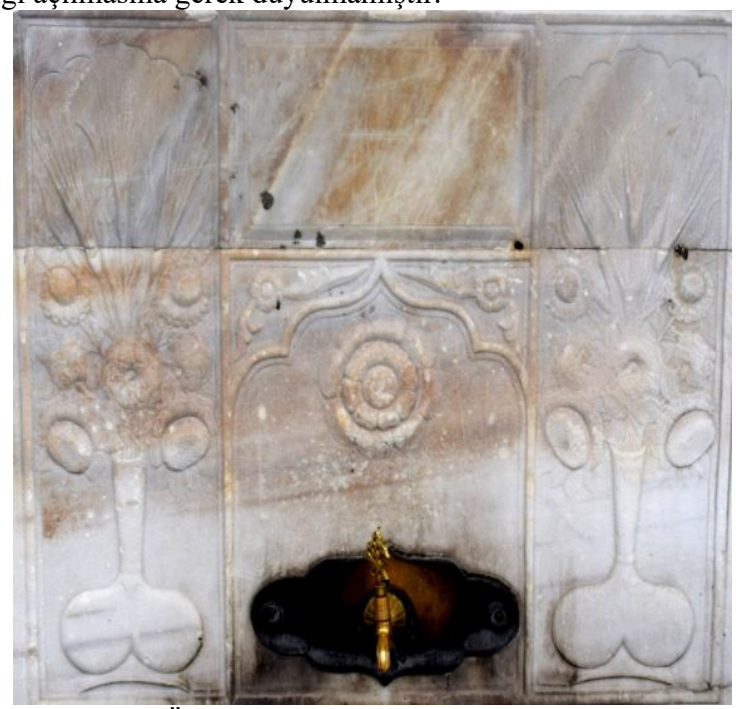

Fotoğraf 3: Üsküdar III. Ahmed Çeşmesi Taş Süsleme

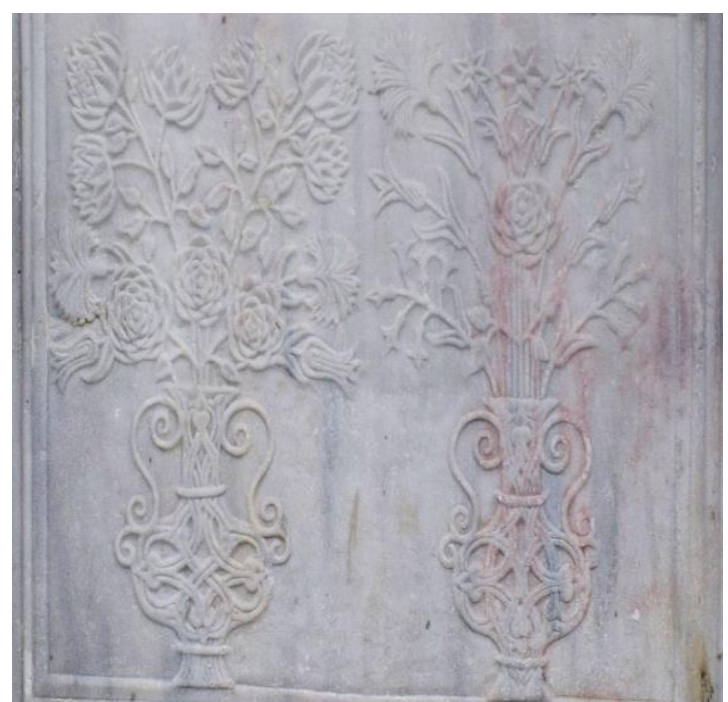

Fotoğraf 4: Yeni Valide Çeşmesi Taş Süsleme

\section{Cami Tas Tezyinâtında Lâle}

\section{Yüzyıl Öncesi}

18. yüzyıl öncesinde lâlenin taş süslemede kullanımını sınırlı da olsa görmek mümkündür. Camilerin genellikle mihrap, minber gibi elemanlarının taş süslemelerinde karşılaşılan lâle kimi zaman sütun başlığı veyahut kapı ve pencere süslemelerinde de karşımıza çıkabilmektedir. Osmanlı sanatında lâle motifinin taş süslemede görüldüğü en erken örneklerden birisi İznik Yeşil Camii'dir. Yap1, üzerindeki kitabelere göre (1378-1392) yılları arasında 1. Murad devrinde Çandarlı Hayreddin Paşa tarafından mimar Hacı b. Mûsâ'ya inşa ettirilmiştir. Caminin mihrap sütuncelerinin alt bölümündeki kaidelerde ters şekilde düzenlenmiş lâle formunda süslemeler bulunmaktadır (Fotoğraf 5). ${ }^{28}$ Söz konusu süslemeler Karahanlılar'dan kalma Özkent türbelerinden 1152 tarihli Celaleddin Hüseyin Türbesi (Kuzey Türbe) taç kapısı kemer köşelerinde stilize lâleler şeklinde sütun başlıklarını hatırlatır. ${ }^{29}$

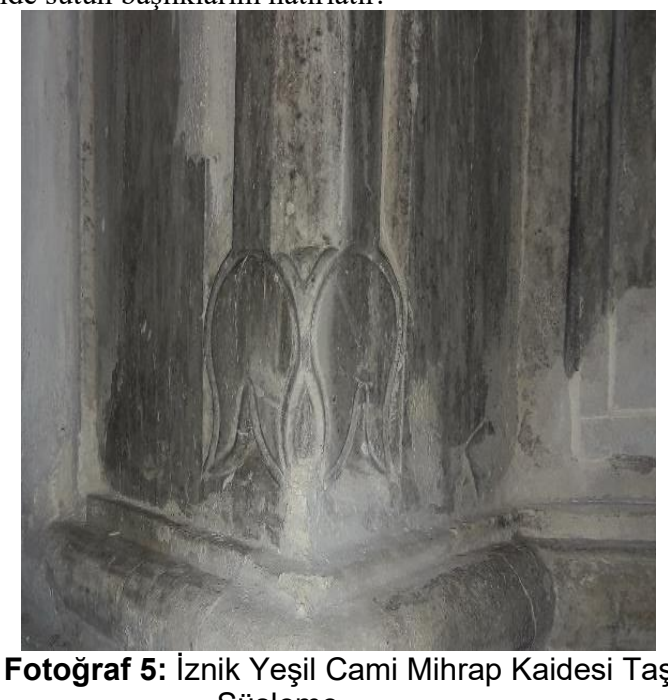
Süsleme

Antakya Habib-i Neccar Camii (13. yy) kuzey cephesindeki konsollar üzerindeki taş tezyînâtta kıvrım dala sıralanmış lâle ve çiçekler ${ }^{27}$ Ali Osman Uysal, "Bolvadin'de Bir Lâle Devri Eseri: Ağılönü Çeşmesi"
Ankara Üniversitesi Dil ve Tarih-Coğrafya Fakültesi Dergisi, Cilt 32 (1-2),
1988, s.33-55.

${ }^{28}$ Yıldıray Özbek, Erken Osmanlı Mimarisinde Tas Süsleme, Basılmamıs Doktora tezi. Hacettepe Üniversitesi Sosyal Bilimler Enstitüsü, 1999, s. 146.
${ }^{29}$ Abdulkadir Dündar, “Özkent Türbeleri ve Minaresinin Türk İslâm Sanatları

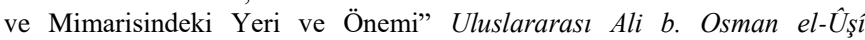
Seтроzуити Bildirileri, (Ed. Ferhat Gökçe), Tika Yayınları, Bişkek, 2018, s. 604, foto, 16. 
bulunur. ${ }^{30}$ Konsollar caminin Osmanlı dönemi onarımları esnasında eklenmiş olmalıdır (Fotoğraf 6).

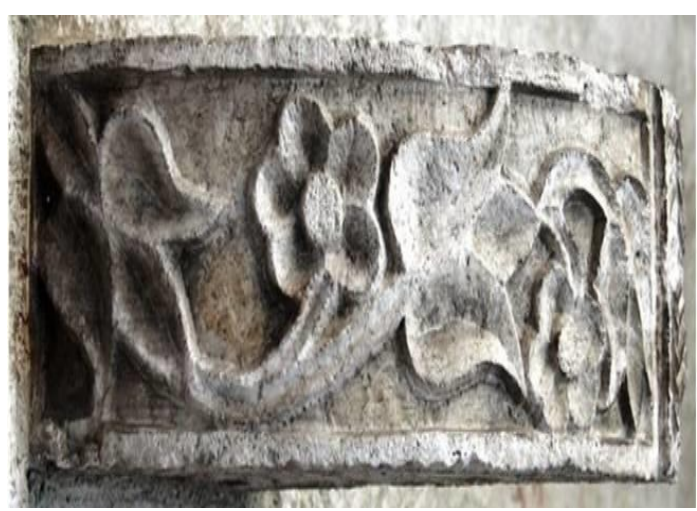

Fotoğraf 6: Antakya Habib-i Neccar Camii Konso Taş Süsleme (Murat Dedeoğlu'ndan)

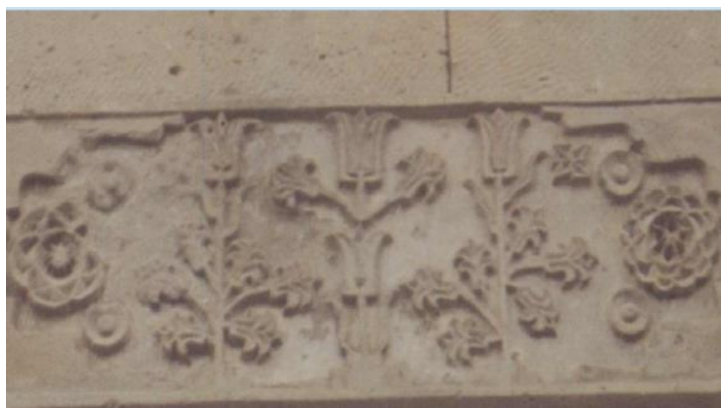

Fotoğraf 7: Kayseri Büyük Bürüngüz Danış Ali Bey Camii Taş Süsleme (Mustafa Denktaş'tan)

Kayseri Büyük Bürüngüz Köyü Danış Ali Bey Camii yazlık (1582) ve kışlık (1587) mescitleri mihrap, minber ve pencerelerin yüzeylerinde, caminin batısındaki türbenin (1587) güney cephesinde gerek tek başlarına gerekse karanfil ve sümbüllerle birlikte işlenmiș lâle motifleri yer almaktadır (Fotoğraf 7). ${ }^{31}$ Lâlelerin bazıları işlendikleri yüzeyin formunu alan dallar üzerinden çıkarken bir kısmı vazolar içerisine yerleştirilmiştir. Caminin kuzey cephesine 1738 yılında bir mutfak mekânının ilave edildiği görülür. Cami ve türbede yer alan bu taş süslemelerin ilk inşalarında mı yoksa mutfak mekânı eklendiği sırada mı yapıldığı kesin değildir. Ancak bu süslemelerin benzerlerinin 1710 tarihli Kayseri Hasinli Camii'de de karşımıza çıktığını söylemek gerekir.

Diyarbakır valisi Behram Paşa tarafından 1564-1572 yıllarından yaptırılan camide taş süslemeler arasında lâle motifleri görülmektedir. ${ }^{32}$ Mihrabın mukarnaslı kavsarasında, mukarnasların aralarındaki sarkıtların uçlarına zemine bakar vaziyette ters lâleler yerleştirilmiştir. $\mathrm{Bu}$ kompozisyonun benzerleri daha natüralist üslupta Nevşehir Damat İbrahim Paşa Camii ve Hekimoğlu Ali Paşa Camii mihraplarında karşımıza çıkmaktadır. Caminin eyvan mihrabında ise kavsaranın iki yanındaki üçgen yüzeylere birer lâle motifi yerleştirilmiştir.

${ }^{30}$ Murat Dedeoğlu, Hatay Cami ve Mescitlerinde Taş Süsleme, Basılmamış Yüksek Lisans Tezi, Selçuk Üniversitesi Sosyal Bilimler Enstitüsü, 2018, s. $11, \mathrm{r} .40$

${ }^{31}$ Mustafa Denktaş, “Kayseri-Büyük Bürüngüz Köyü’ndeki Türk Anıtları”, Vakıflar Dergisi, 27, 1998, s.163-166, r.6-23

32 Gülsen Baș, Diyarbakır'daki İslam Dönemi Mimarisinde Süsleme, Basılmamış Doktora Tezi, Yüzüncü Y1l Üniversitesi Sosyal Bilimler Enstitüsü, 2006, s.129.

33 Baș, Diyarbakır'daki İslam..., s.40-51.

34 Tuncer Doğan, Gaziantep Türk-İslam Dönemi Mimari Süslemeleri, Basılmamıș Doktora Tezi, Yüzüncü Y1l Üniversitesi Sosyal Bilimler Enstitüsü, 2013, s. 82, r.129.
Diyarbakır Ulu Cami (1091) 'ye 18. yüzyllda eklenen minberin süslemelerinde gerek tek başına gerekse farklı çiçeklerle birlikte işlenmiş lâle tasvirleri bulunmaktadır. Minberin mihrap ile birlikte 1712 yılında Maktulzade Vezir Paşa'nın valiliği döneminde Kethüda Hüseyin Paşa tarafından eklendiği bilinmektedir. ${ }^{33}$ Minberin giriş kısmında, kemer köşelerine üçgen yüzeyin formunu alan iki zarif lâle motifi işlenmiştir. Tek daldan çıkan lâlelerin iki yanında küçül lâleler ve yapraklar bulunur. Kapının iki yanındaki bordürlerde ise merkezde lâlenin yer aldığı stilize kompozisyonlar görülmektedir. Minberin ahşap kapı kanatlarında da yapıldığı dönemin üslubunu aksettiren vazolu lâle kompozisyonları karşımıza çıkmaktadır.

Gaziantep Şeyh Fethullah Camii (16. yy) taç kapısının yivli sarkıtlarında uçları zemine bakan lâleler bulunmaktadır. ${ }^{34}$ Mihrabının kemer köşelerindeki üçgen yüzeylere işlenen lâle motifleri ise yukarıda verilen örneklerle benzer özellikler göstermektedir (Fotoğraf 8). ${ }^{35}$ Ancak bu mihrapta ortadaki kabaraların iki yanına ikişer lâle motifi yerleştirilmiştir. Bir daldan çıkan lâlelerin iki yanında daha küçük çiçekler bulunmaktadır.

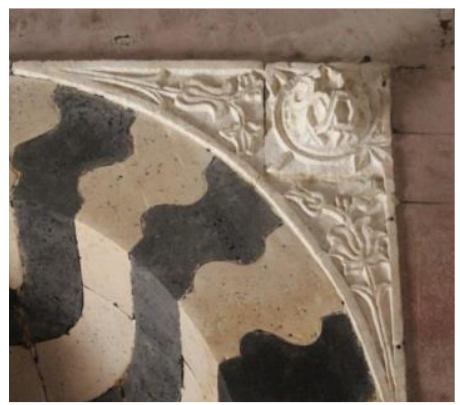

Fotoğraf 8: Gaziantep Şeyh Fethullah Camii Mihrap Taş Süsleme (Nebi Butasım'dan)

Gaziantep Bekirbey Camii (1648) mihrap kavsarasında, yivli sarkıtların uçlarına zemine bakar vaziyette ters lâleler yerleştirilmiştir. ${ }^{36}$ Şanlıurfa Nimetullah Camii (16. yy) mihrap kavsarasında da benzer süslemeler görülmektedir. ${ }^{37} \mathrm{Bu}$ mihraptaki lâleler ince uzun formlarıly daha zarif bir görünüm sergilerler. Bu tarz uygulamalar yukarıda da belirtildiği üzere farklı bölgelerde ve tarihlerde yapılan bazı mihrapların süslemelerinde karşımıza çıkabilmektedir.

Isparta Firdevs Bey Camii (1561) mihrabında kavsara köşelerindeki madalyonlar içerisine yerleştirilen sekizgenlerin uçları stilize lâlelerle bitirilmiştir. Kavsarayı çevreleyen dilimli kemerin sondan üçüncü kademesinde ise dikdörtgen panolar içerisinde birer lâle ve karanfil motifi yerleştirilmiştir (Fotoğraf 9). ${ }^{38}$ Tek daldan çıkan lâle natüralist bir görünüm sergilemektedir.
35 Nebi Butasım, Güneydoğu Anadolu Bölgesi'nde Osmanll Dönemi Mihraplarl (1515-1915),Basılmamış Doktora Tezi, Yüzüncü Y1l Üniversitesi Sosyal Bilimler Enstitüsü, 2016, r.97.; Doğan, Gaziantep Türk-İslam..., s.84, r. 142 .

${ }^{36}$ Butasım, Güneydoğu Anadolu..., s.90-91.

${ }^{37}$ Butasım, Güneydoğu Anadolu..., s.162-164.

38 Beste Çok, Isparta ve İlçeleri Camii Süslemeleri, Basılmamış Yüksek Lisans Tezi. Süleyman Demirel Üniversitesi Sosyal Bilimler Enstitüsü, 2010, s.35-36. 


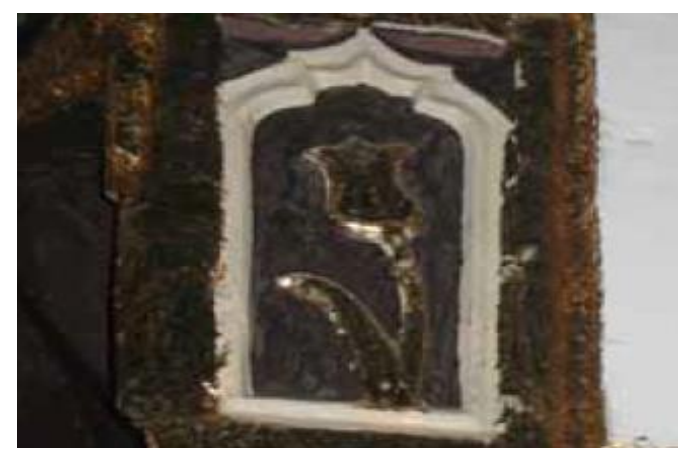

Fotoğraf 9: Isparta Firdevs Bey Camii Mihrap Süslemesi (Beste Çok'tan)

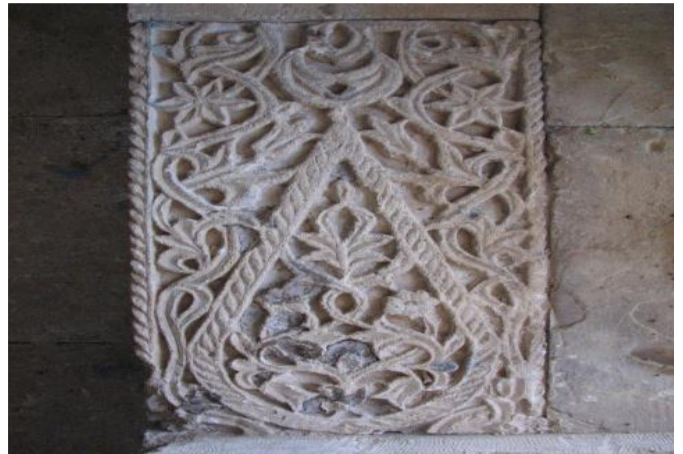

Fotoğraf 10: Mardin Zairi Camii Pencere Taş Süsleme (Gülnaz Güzel'den)

Mardin Zairi Camii (1690) pencerelerinin taş süslemelerinde lâle motifinin de yer aldığı bitkisel süslemeler görülmektedir. Pencerelerin alt tarafına yerleştirilen taş levhalardaki oymalarda lâleler yıldız çiçeği, palmet, rûmî, tomurcuk, kıvrım dallar ve yapraklardan müteşekkil grift kompozisyonların merkezine yerleştirilmiştir (Fotoğraf 10). ${ }^{39}$

Mimar Sinan yapılarında lâle motifinin çoğunlukla çini süslemede kullanıldığı görülse de yapıların taş tezyînâtına şöyle bir göz atıldığında lâlenin izleriyle karşılaşabilmek mümkündür. Süleymaniye Camii (1550-1557) son cemaat yeri revağ1 sütün başlıklarından birisinde mukarnaslar arasında, dikdörtgen bir kartuş içerisinde zarif bir lâle motifi yer almaktadır (Fotoğraf 11). ${ }^{40}$

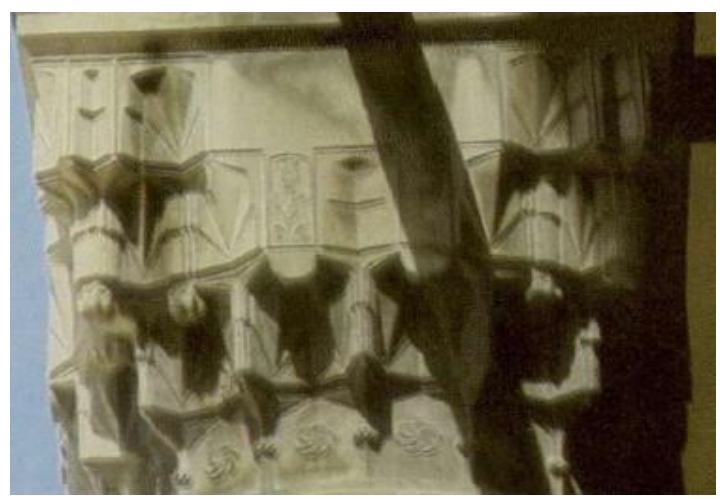

Fotoğraf 11: Süleymaniye Camii Revak Sütun başlığı (Yıldız Demiriz'den)

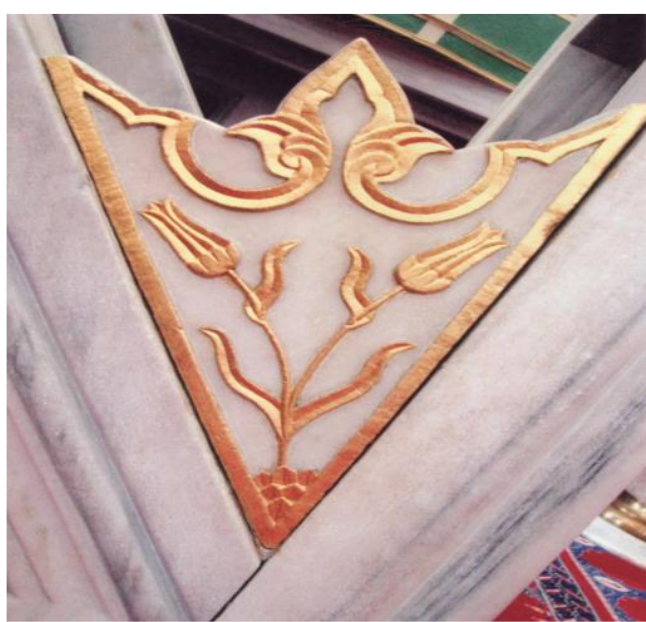

Fotoğraf 12: Atik Valide Camii Minber (Bülent Oral'dan)

Atik Valide Camii (1570-1583) mermer minberinde, yan korkuluklarla giriş kapısının birleştiği bölümde üçgen yüzeyde iki lâle motifi görülür. İnce-uzun formlu zarif lâleler bir kökten çıkan iki dala yerleştirilmiştir (Fotoğraf 12). ${ }^{41}$

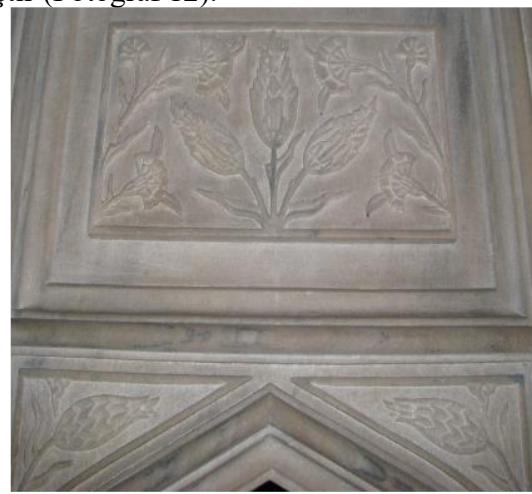

Fotoğraf 13: Rüstem Paşa Camii Minber (Bülent Oral'dan)

Rüstem Paşa Camii (1555-1561) minberinin geçit açıklığı kemeri üçgen köşelerinde ve üstteki alınlık kısmında yine tek başına lâle motiflerine yer verilmiştir. Bu minberlerdeki lâleler yapıların çini süslemelerinde görülen yarı stilize lâlelerle aynı forma sahiptir (Fotoğraf 13). ${ }^{42}$

Edirne Selimiye Camii'nde (1568-1574) ise müezzin mahfili mermer ayaklarının birisine ters lâle motifinin bilerek mi yoksa yanlışlıkla mı bu düzende yapıldığı belirsizliğini korumaktadır.

Mimar Sinan sonrası selâtin camilerinden Sultan Ahmed Camii (1603-1617) mihrabı kemer köşeleri ve taç kısmında stilize lâleler, karanfil, hatâî, penç ve hançer yapraklarıyla birlikte işlenmiştir (Fotoğraf 14). ${ }^{43}$ Söz konusu kompozisyonlarda yer alan lâleler Rüstem Paşa Camii'nde olduğu gibi dönemin çini süslemelerinde karşılaşılan lâle tasvirleriyle paralellik göstermektedir. Yine aynı caminin fil ayaklarının birisinde çeşme üzerinde vazodan çıkan yarı stilize çiçekler arasında lâleler de yer alır.

1694 yılında Bektaşi Hacı Hasan tarafından inşa ettirilen Niğde Kığılı (Pazar) Camii'nde inşa kitabesinin iki alt kösesinde simetrik

\footnotetext{
${ }^{39}$ Gülnaz Güzel, Mardin'deki Osmanlı Dönemi Mimari Yapılarında Taş Süsleme, Basılmamış Yüksek Lisans Tezi, Yüzüncü Yıl Üniversitesi Sosya Bilimler Enstitüsü, 2010, s.22-23.

${ }^{40}$ Yıldız Demiriz, "Sinan'ın Mimarisinde Bezeme", Mimarbaşı Koca Sinan Yaşadığ Çă̆ ve Eserleri, Cilt:2, (Ed. Sadi Bayram), Vakıflar Genel Müdürlüğü Yayınları, İstanbul, 1988, r.242.
}

${ }^{41}$ Bülent Oral, Mimar Koca Sinan'ın İstanbul'daki Camilerinde Minber, Basılmamış Doktora Tezi, Gazi Üniversitesi Sosyal Bilimler Enstitüsü, 2014, s.66, r. 17 .

${ }^{42}$ Oral, Mimar Koca Sinan'1n..., s.204, r.108-109.

${ }^{43}$ Tolga Bozkurt, Osmanlı Selâtin Cami Mihrapları, Basılmamış Doktora Tezi, Selçuk Üniversitesi Sosyal Bilimler Enstitüsü, 2007, s.140-144, r.175177 
yerleștirilmiş birer lâle motifi bulunmaktadır. Yarı stilize tasvir edilen lâleler birer kartuş içerisine alınmıştır (Fotoğraf 15). ${ }^{44}$

18. yüzyıl öncesinde lâle motifinin taş süslemede kullanımı hiç azımsanmayacak düzeydedir. Çoğunlukla stilize olarak işlenen lâlenin kimi örnekte natüralist olarak yorumlayabileceğimiz formda nakşedilmesi, 17. yüzyıl içerisinde bir takım denemelerin yapıldığını gösterir. Lâle Devri başta olmak üzere 18. yüzyıl içerisinde lâlenin çoğunlukla çeşme ve sebillerin taş tezyînâtında kullanıldığı kabul görür. Gerçekten de sivil yapıların süsleme programlarında natüralist lâleler dönemin diğer gözde çiçekleriyle beraber önemli bir yer tutmaktadır. Buna karşın gerek İstanbul'da gerekse Anadolu'nun farklı şehirlerinde inşa edilen camilerin bir kısmında lâlenin taş tezyînât içerisinde kendine yer bulduğu görülür. Bu durum görülmesi 18. Yüzyıl öncesinde çoğunlukla çini ve kalem işi süslemelerde özdeşleşen lâle motifinin işlendiği malzeme çeşidini göstermesi bakımından önemlidir. Camilerdeki 18. yüzyıl öncesi taş tezyînâtta tespit edebildiğimiz lâle tasvirlerinin yanı sıra Edirne Yıldırım İbrahim Çeşmesi (1669) mermer kitabesinin iki yanında vazoda natüralist lâle, karanfil ve güller bulunması, Lâle Devri öncesinde bu üsluba dair örneklerin farklı yapılar üzerinde mevcut olduğunu göstermesi bakımından kıymetlidir.

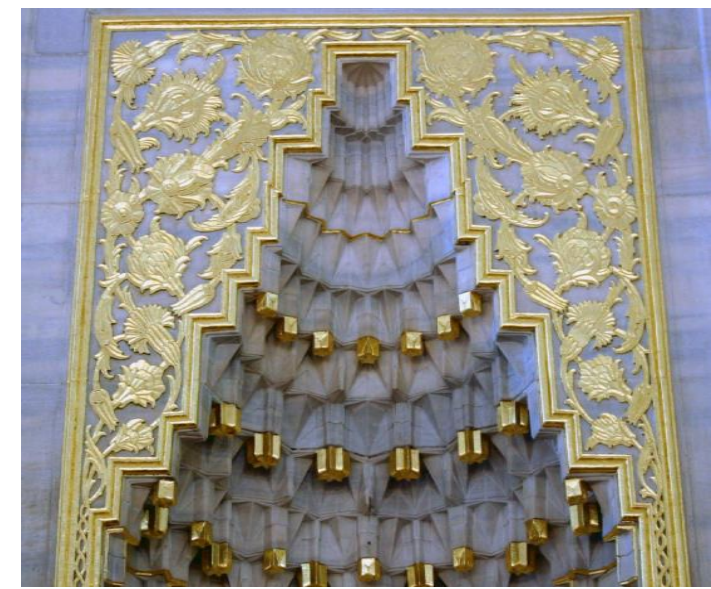

Fotoğraf 14: Sultan Ahmed Camii Mihrabı (Tolga Bozkurt'dan)

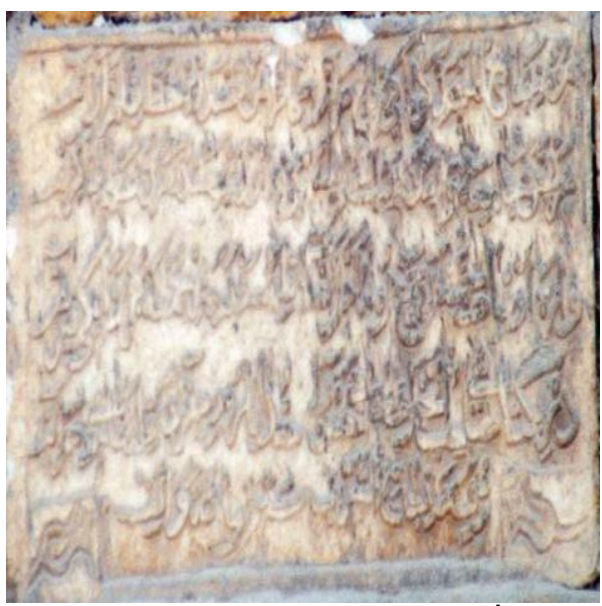

Fotoğraf 15: Niğde Kığılı (Pazar) Camii İnşa Kitabesi (Mehmet Özkarcı'dan)

\section{Yüzyıl}

3. Ahmed ve Nevşehirli Damad İbrahim Paşa ile özdeşleşen ve lâle çiçeğine olan sevgiden ötüre sonradan "Lâle Devri" olarak

\footnotetext{
${ }^{44}$ Mehmet Özkarc1, Türk Kültür Varlıklarl Envanteri Niğde 51, Cilt:1, Türk Tarih Kurumu Yayınları, Ankara, 2014, s.176-187, r.13.
}

adlandırılan yıllar, Osmanlı sanatında daha önceki asırların genel anlayışından farklı bir takım uygulamaların hayata geçirildiği bir geçiş dönemi olarak karşımıza çıkar. Başkentte filizlenen bu yeni üslubun ortaya çıkmasında dönemin sosyal yapısı, siyasi ilişkileri, kültürel etkileşimleri ve tabi ki saray erkânının düşünce yapısının etkisi büyüktür. Bir başkent üslubu olarak nitelendirebileceğimiz bu sanat anlayışının, saray bağlantılı simalarla Anadolu'nun çeşitli merkezlerine taşındığı da bir gerçektir. $\mathrm{Bu}$ doğrultuda dönem yapılarına baktığımızda Anadolu'da hiç de azımsanmayacak sayıda bu yeni üslubu yansıtan mimari eserlerle karşılaş11ır. Lâle Devri ile başlayan bu sürecin 18 . yüzyıl içerisinde daha sonraki yıllarda da devam ettirildiği görülür.

3. Ahmed tarafindan yaptırılan Yeni Valide Camii'nin (1708-1710) minberinde, hünkâr mahfili mihrabında ve șadırvanında dönemin üslubuna uygun lâle ağırlıklı bitkisel kompozisyonlar yer alır. Minber köşkünün altındaki panolarda dekoratif kemerli nişlerin iki yanındaki boşluklar vazodan çıkan zarif lâlelerle süslenmiştir. Caminin sekizgen şadırvanının her yüzünde sivri kemerin iki yanındaki üçgen boşluklarda yine natüralist üslupta vazolu çiçek kompozisyonları görülür (Fotoğraf 16). Bu kompozisyonun merkezinde ince, uzun formlu lâleler yer alır. Hünkâr mahfilinin mihrabında ise niși çevreleyen bordürün içinde servi ağacı, asma dalları ve güllerle beraber stilize lâle motifleri bulunur. Söz konusu kompozisyonların benzerleri Kayseri Hasinli Camii (1714), Şehzadebaşı Damad İbrahim Paşa Camii (1720), Üsküdar Ahmediye Camii (1722), Nevşehir Damad İbrahim Paşa Camii (1727), Topkapı ve Üsküdar'daki 3. Ahmed Çeşmeleri (1728) gibi Lâle devri yapılarında ve Bereketzade Çeşmesi (1732), Tophane Çeşmesi (1732), Azapkapı Saliha Sultan Çeşmesi (1732) ve Bolvadin Ağılönü Çeşmesi (1748) gibi Lâle Devri'nin hemen sonrasında inşa edilen eserlerde karşımıza çıkmaktadır. Her bir yapıdaki kompozisyonlarda ufak ayrıntılar dışında şişkin gövdeli, ince uzun boyunlu vazolardan buğday başağını andıran ince uzun lâleler ve güller çıkar. Lâleler kompozisyonların üst bölümünü oluşturur. Genellikle üç lâle ve iki yandaki güllerden oluşan tasvirler kimi zaman düz dikdörtgen kartuşlar içerisinde kimi zaman dilimli kemerli nişler içerisinde karşımıza çıkarlar.

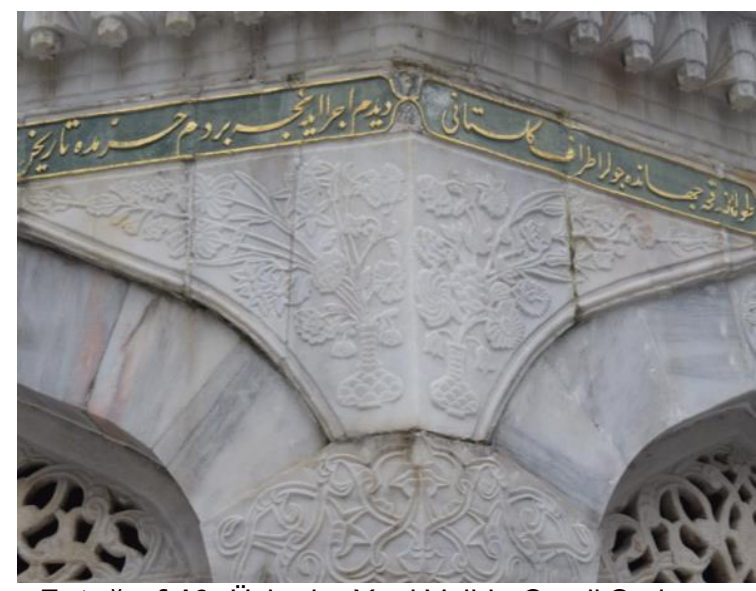

Fotoğraf 16: Üsküdar Yeni Valide Camii Şadırvan

3. Ahmed'in sadrazamlarından Çorlulu Ali Paşa'nın 1707 yılında Çarşıkapı'da yaptırdığı caminin cümle kapısı üzerinde, yuvarlak kemerin iki yanındaki üçgen boşluklarda kabartma olarak işlenmiş lâleler bulunur (Fotoğraf 17). ${ }^{45}$ İki uçtaki lâlelerde Yeni Valide Camii'ndeki gibi bir natüralist üsluptan söz etmek mümkün değildir.

${ }^{45}$ Duygu İlkhan Söylemez, Batılılaşma Dönemi Ístanbul Cami Cephelerinde Tas Süsleme (1703-1839), Basılmamıș Doktora Tezi, Selçuk Üniversitesi Sosyal Bilimler Enstitüsü, 2010, s.26-27, r.6-7. 


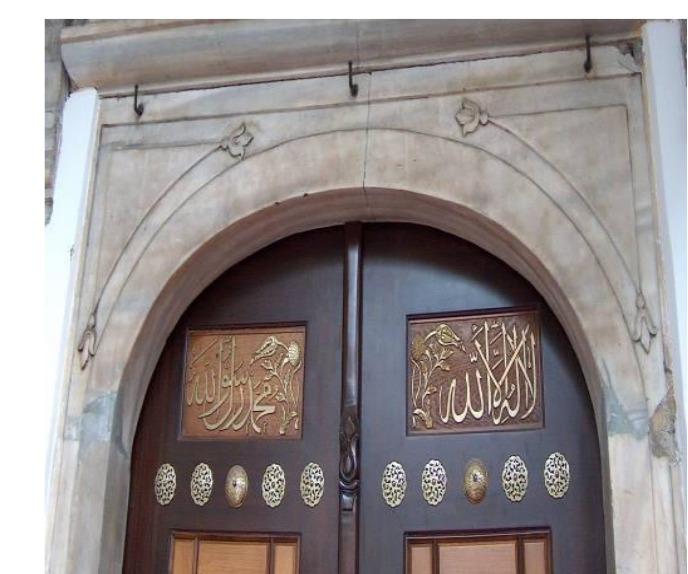

Fotoğraf 17: Çorlulu Ali Paşa Camii Cümle Kapısı (Duygu İlkhan Söylemez'den)

Lâle Devri'nin simge ismi Nevşehirli Damad İbrahim Paşa'nın hanımı Fatma Sultan ile birlikte 1720 yılında Şehzadebaşı'nda yaptırdığı külliyede, mescidin giriş kapısı sövelerinde içte ve dışta simetrik yerleştirilmiş vazolu çiçek kompozisyonları bulunur. Alt sıradaki vazolarda, ortada lâleler iki yanda ise güller yer alır. İnceuzun formlu lâlelerin buğday başağını andıran zarif formları dönemin çeşmelerinde de karşımıza çıkmaktadır. Bu kompozisyonların benzerleri külliyenin haziresindeki mezar taşlarında da görülür (Fotoğraf 18-20).
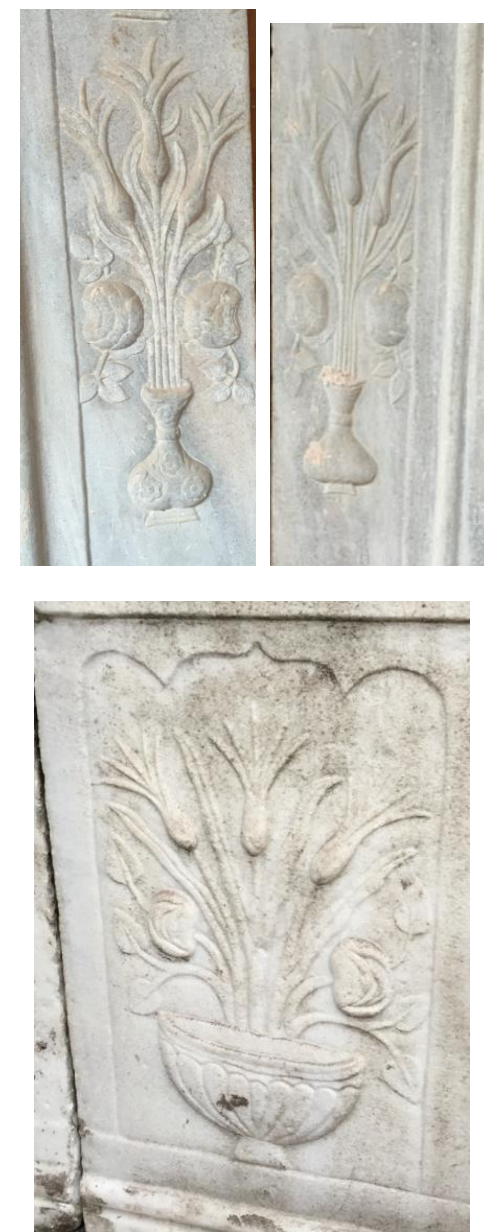

Fotoğraf 18-20: Şehzadebaşı Damad İbrahim Paşa Camii ve Haziresi Taş Süslemeler

${ }^{46}$ Gülçin Erol Canca, "Üsküdar Ahmediye Külliyesi ve Lale Devri Mimarisi İçinde Bir Değerlendirme”,
Eminzade Hacı Ahmed Ağa tarafindan 1722 yılında Üsküdar'da yaptırılan caminin mermer minberinde biraz önceki örnekte karşılaşı̆ğımız gibi natüralist vazolu çiçek kompozisyonuna yer verilmiștir. Minber köşkünün hemen altında, korkulukla birleștiği bölümde dikdörtgen pano içerisine alınan süslemede ince boyunlu vazodan lâleler ve güller çıkmaktadır (Fotoğraf 21). ${ }^{46}$

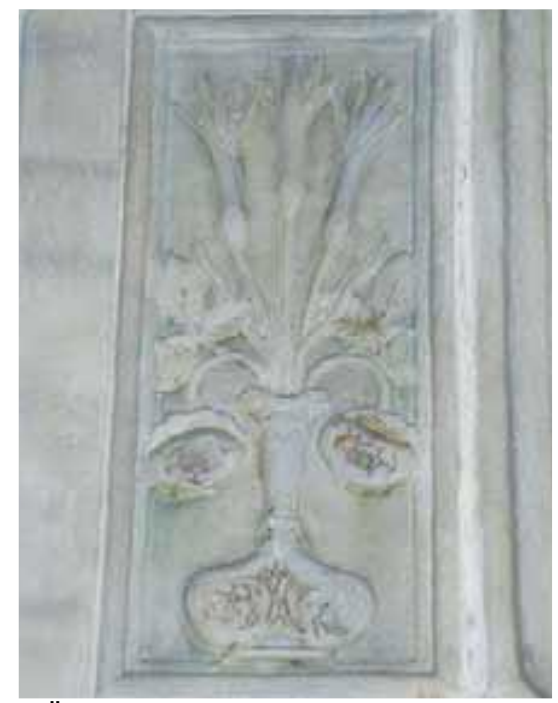

Fotoğraf 21: Üsküdar Ahmediye Camii Minber (Gülçin Erol Canca'dan)

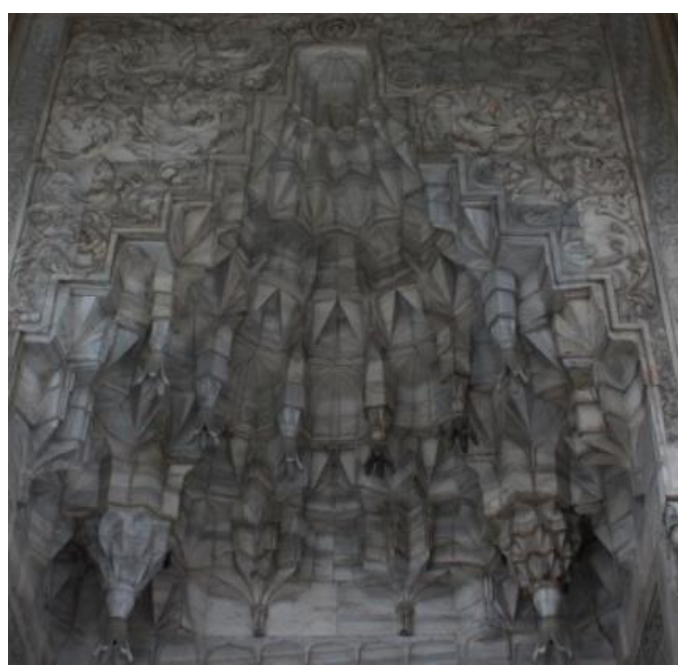

Fotoğraf 22: Hekimoğlu Ali Paşa Camii Mihrap

Lâle Devri'nin hemen sonrasında 1734 yılında Hekimoğlu Ali Paşa tarafından yaptırılan caminin cümle kapısında, batı kapısında, mihrabında ve kubbeyi taşıyan fil ayağında taş süslemeler içerisinde lâle motifine yer verilmiştir. Cümle kapısının mukarnaslı kavsarasında, mukarnasların aralarına zemine bakar vaziyette ters lâleler yerleştirilmiştir. Kavsara köşelerindeki üçgen boşluklarda ise kıvrım dallar arasında yapraklar ve rûmîlerle birlikte lâleler bulunur. Caminin batı kapısı alınlığında palmet, rûmî ve kıvrım dallardan müteşekkil bitkisel kompozisyon en üstte lâleyi andıran bir motifle sonlandırılmıştır. Yapının mihrabında ise cümle kapısındaki tezyînâtın benzerleri karşımıza çıkar (Fotoğraf 22). Kavsarada ters lâleler yer alırken kemer köşelerinde kıvrım dallar arasında stilize lâleler görülmektedir. Ayrıca sütunceler üzerinde beş kollu çiçeklerle birlikte yine stilize lâlelere yer verilmiștir. İç mekânda fil ayaklarından birisi üzerinde bulunan çeşmede, musluğun iki yanına, dilimli kemerli niş içine bir daldan çıkan birer lâle motifi yerleştirilmiştir. $\mathrm{Bu}$ uygulamanın benzeri daha önceki yüzyılda

VI. Uluslararası Üsküdar Sempozyumu, Cilt: 1, Üsküdar Belediyesi Yayınları, İstanbul, 2008, s. 200. 
Sultan Ahmed Camii'nde (1603-1617) görülür. Taçkapı ve mihrap kavsaralarında görülen mukarnaslar arasındaki ters lâlelerin benzerleri ise Diyarbakır Behram Paşa Camii (1564-1572), Gaziantep Şeyh Fethullah Camii (16. yy), Gaziantep Bekirbey Camii (1648) ve Şanlıurfa Nimetullah Camii (16. yy) gibi daha önceki yüzyıllarda inşa edilen camilerin taç kapı ve mihrap süslemelerinde karşımıza çıkmaktadır.

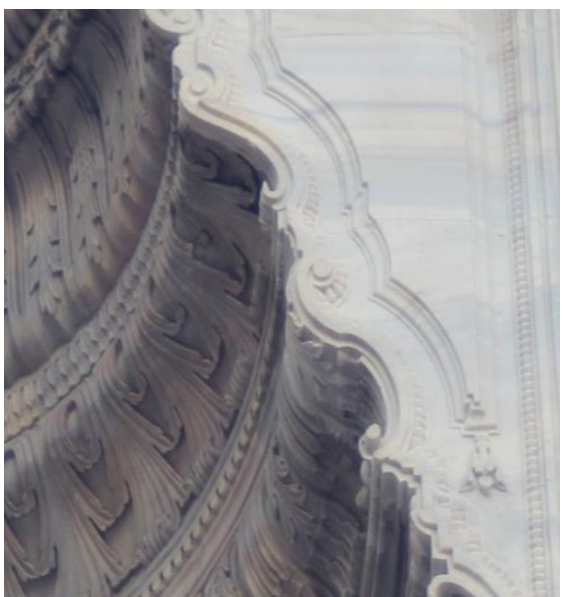

Fotoğraf 23: Nuriosmaniye Camii Avlu Taçkapısı

18. yüzyılın ortalarında inşa edilen Nuriosmaniye Camii'nde (17491755) avlu taç kapısı kemerinin iki yanında yer alan çerçevelerin uçlarında, zemine bakar vaziyette ters lâleler bulunmaktadır (Fotoğraf 23). Bulunduğu yer ve işlenişi bakımından Çorlulu Ali Paşa Camii kapısındaki bezemeleri hatırlatsa da buradaki lâlelerin daha natüralist bir üsluba sahip olduğu görülür.

Anadolu'daki camilerde ise en dikkat çekici örnekler arasında dönemin simge ismi Nevşehirli Damad İbrahim Paşa'nın memleketine yaptırdığ camiler yer almaktadır. ${ }^{47} \mathrm{Bu}$ yapılardan ilki olan Kara Camii (1718) avlu giriş kapısı kemer köşelerinde karşılıklı yerleştirilmiş lâle motifleri ince-uzun formlarıyla dönem üslubunu aksettirirler (Fotoğraf 24/ Çizim 1). Cami minberinin aynalarında süslemeler tahrip olsa da, aralarında lâlelerin yer aldı ̆̆ 1 bir takım bitkisel kompozisyonların izleri mevcuttur.
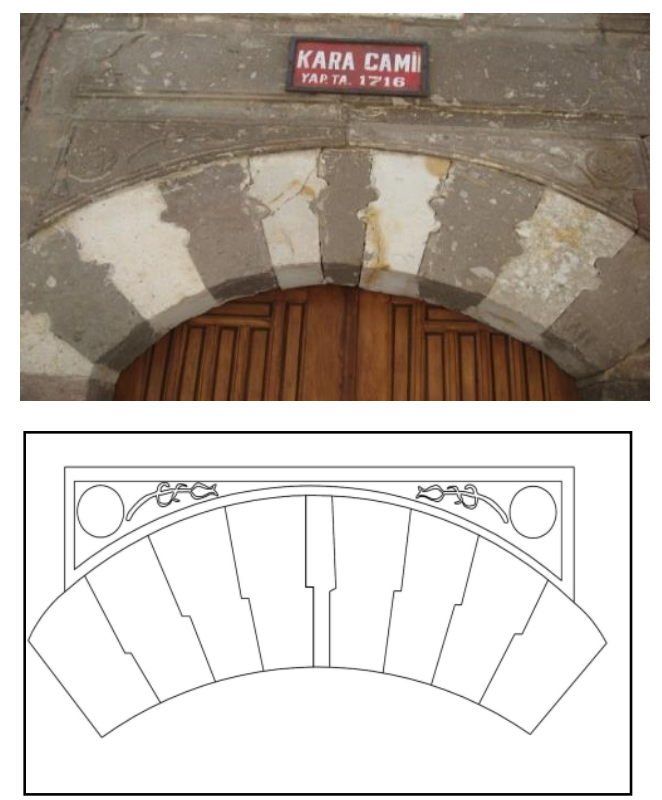

Fotoğraf 24: / Çizim 1: Nevşehir Kara Camii Avlu Giriş Kapısı Taş Süsleme

Damad İbrahim Paşa'nın bu yapıdan 10 yıl sonra yaptırdığ külliyenin camisinde ise İstanbul yapılarının kalitesinde taş tezyînâtlar göze çarpar. Mihrap kavsarasında mukarnasların arasına yerleştirilen ters lâlelerin yukarıda da belirtildiği gibi önceki yüzyıllarda farkl bölgelerde inşa edilen camilerde de karşımı çıktığı görülür. Ancak bu camideki lâleler ince uzun formlarıyla dönem üslubunun genel özelliklerini aksettirirler (Fotoğraf 26). Söz konusu uygulamanın benzeri daha sonra Hekimoğlu Ali Paşa Camii mihrabında da tekrar edilmiştir. Minberin süpürgelik bölümünde ise dilimli kemerli nişler içerisinde alçak kabartma tekniğinde vazolu çiçek kompozisyonları işlenmiştir (Fotoğraf 25/ Çizim 2). Buğday başağını andıran inceuzun lâleler başkentteki çağdaş yapılarda görülen bezemelerin aynısıdır. Bu durum Damad İbrahim Paşa'nın külliyedeki süslemeleri İstanbul'dan getirttiği ustalara yaptırdığını gösterir.
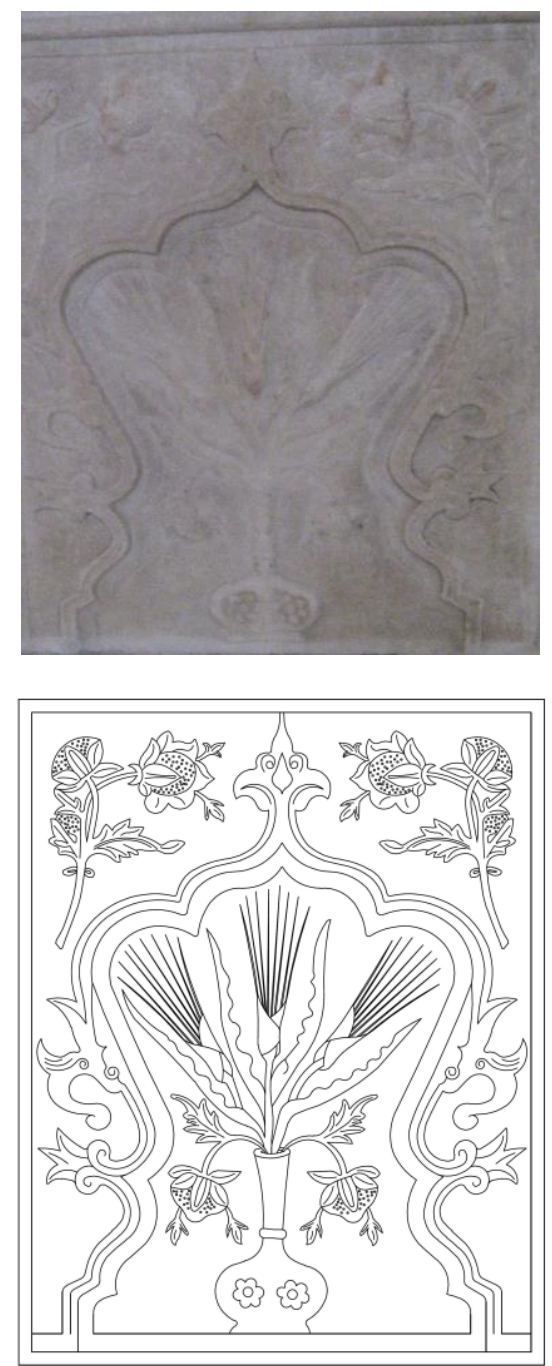

Fotoğraf 25 / Çizim 2: Nevşehir Damad İbrahim Paşa Camii Minber Taş Süsleme

47 Erkan Atak, Anadolu Camilerinde Lâle Devri Üslubu, Gece Akademi, Ankara, 2019, s.62-68, 79-86. 


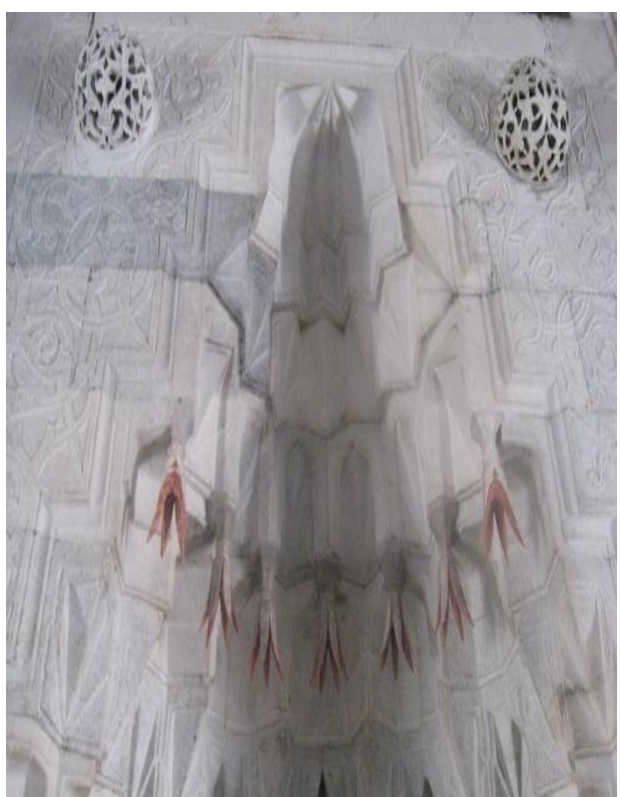

Fotoğraf 26: Nevşehir Damad Ibrahim Paşa Camii Mihrap

Kayseri'de Ürgüplü Derviş Mehmed Ağa tarafından 1714'de yaptırılan Hasinli Camii için ayrı bir parantez açmak gerekir. Zira bu yapının bünyesinde yer alan taş süslemelerin zenginliğini ne İstanbul'da ne de Anadolu'daki çağdaş yapılarda görebilmek mümkün değildir. Camide taçkapı, pencereler, mihrabiyeler, mihrap ve de minberde Lâle Devri'nin genel anlayışını yansıtan natüralist çiçek kompozisyonları yer almaktadır. Lâleler diğer çiçeklerle birlikte kimi zaman tek başlarına kimi zaman ise bir vazo içerisinde işlenmiştir. Bu yapı yukarıda isimlerini verdiğimiz camilerde görülen süslemelerin yer, kompozisyon ve içeriklerinin adeta bir araya toplanmış halidir. Lâle Devri'ne göre erken bir tarihte inşa edilen caminin bu denli zengin bir süsleme programına sahip olması ayrıca önemlidir. Zira bizim makalenin farklı yerlerinde vurgulamaya çalıştığımız Lâle Devri ile özdeşleştirilen bu tarz kompozisyonların nispeten erken tarihli yapılarda da karşımıza çıkabildiğini gösterir (Fotoğraf 27-29/Çizim 3-4). ${ }^{48}$

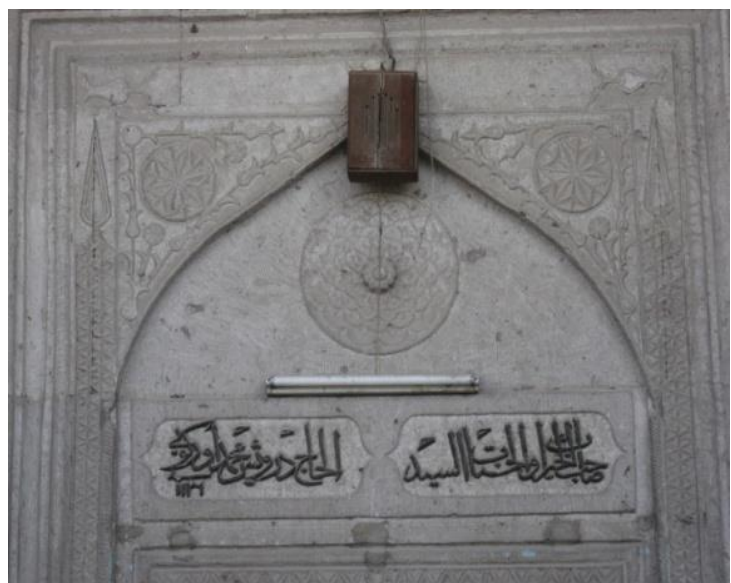

Fotoğraf 27: Kayseri Hasinli Camii Cümle Kapısı Taş Süsleme
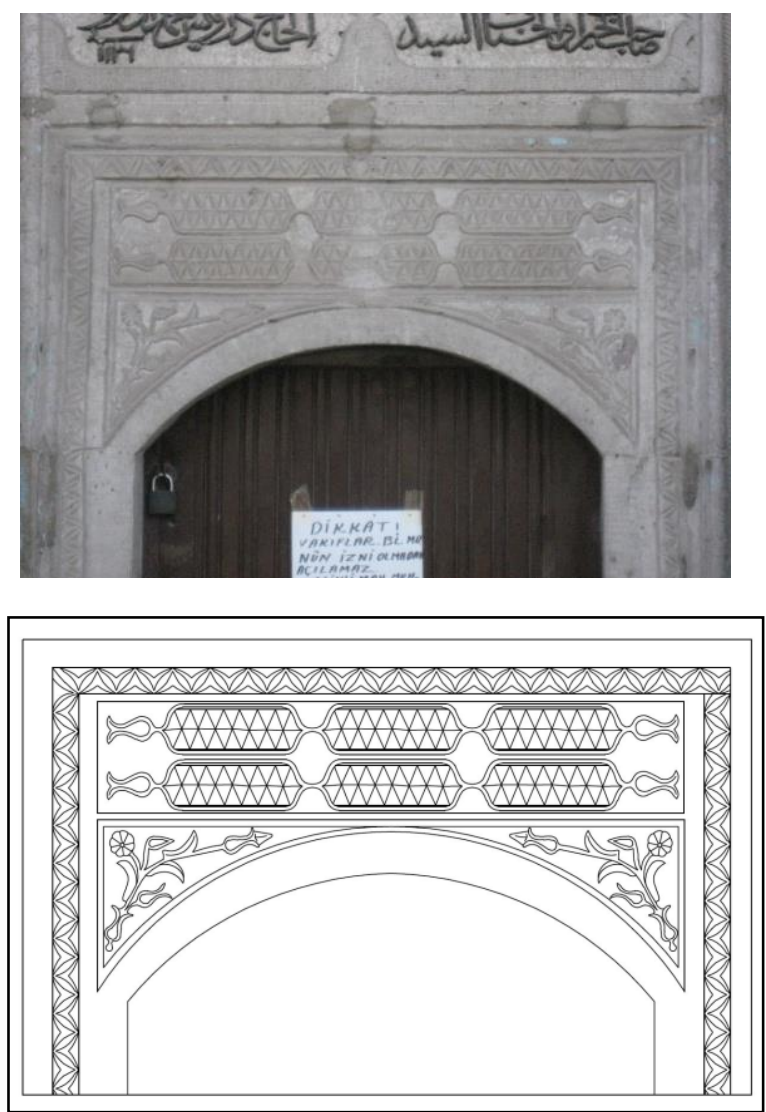

Fotoğraf 28: / Çizim 3: Kayseri Hasinli Camii Cümle Kapısı Taş Süsleme
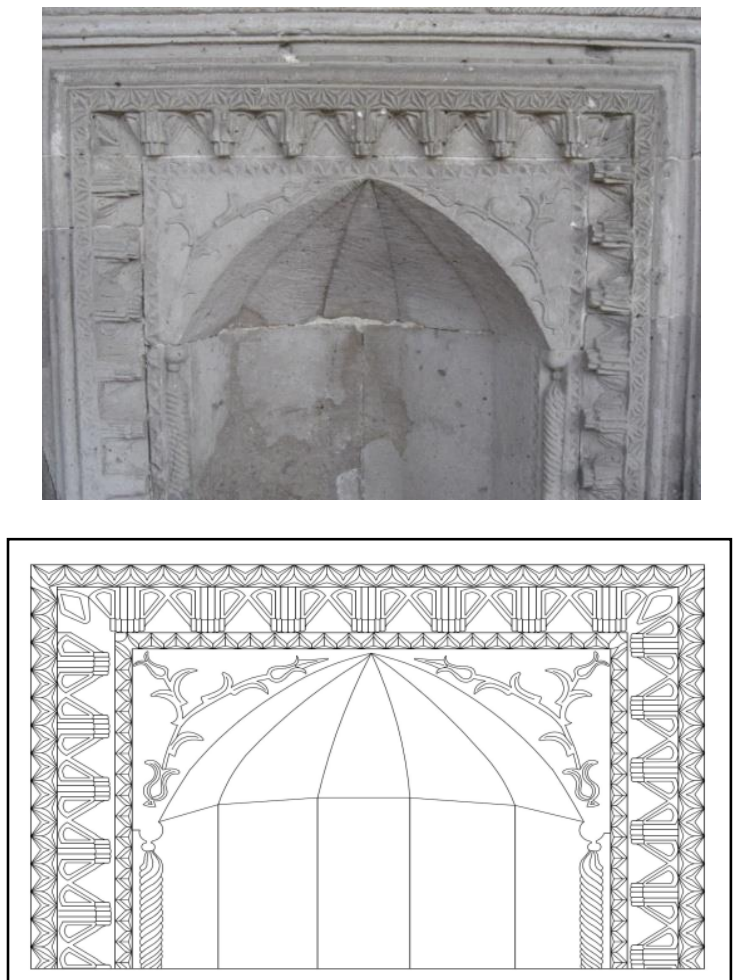

Fotoğraf 29: / Çizim 4: Kayseri Hasinli Camii Mihrabiye Nişi Taş Süsleme

18. yüzyılın ilk çeyreğinde Anadolu'da inşa edilen diğer camilerine baktığımızda; Yüzyılın hemen başlarından Ali Hoca Camii (1708)

${ }^{48}$ Erkan Atak, "Kayseri'de Bir Lâle Devri Eseri: Hasinli Camii”, Sosyal Bilimler Araştırmaları Dergisi, Cilt: 9, Sayı:2, 2014, s. 43-63. 
mihrabındaki vazodan çıkan lâleler dikkat çekicidir. Kayseri’deki bir diğer eser, Molu Köyü Camii'nde (1713) ise mihrap, minber ve inşa kitabesinde Ali Hoca Camii'ndekine benzer lâleler bulunur. Ancak buradaki motifler daha natüralist işlenmiştir (Fotoğraf 30). Bu örneklerin dışında Afyon Yeni Camii (1711) inşa kitabesinde yazı aralarında, Merzifon Çay Camii (18. Yy başları) mihrabının bordüründe ve Adana Yeni Camii (1724) avlu giriş kapısının kemer köșelerinde benzer özelliklerde lâleler görülür (Fotoğraf 31). ${ }^{49}$ Yapılardaki vazolu çiçek tasvirlerinin merkezinde yer alan ince uzun formlu lâleler genellikle kompozisyonların üst kısımlarına yerleştirilmiştir.

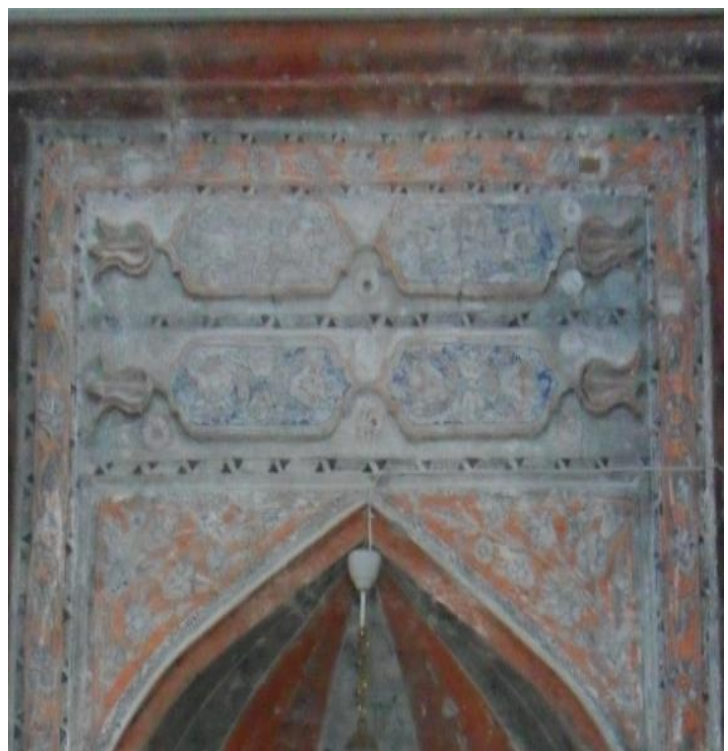

Fotoğraf 30: Kayseri Molu Köyü Camii Mihrap Süsleme

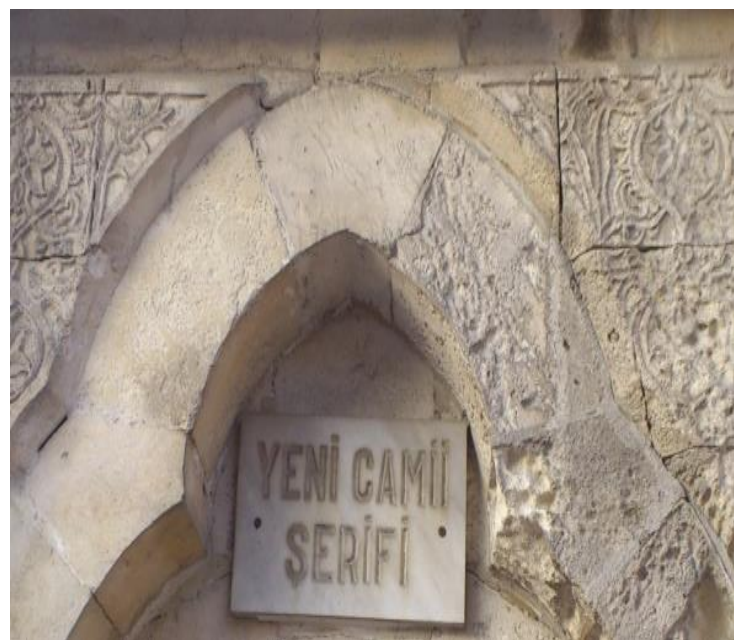

Fotoğraf 31: Adana Yeni Camii Avlu Giriş Kapısı Taş Süsleme

Yüzyılın ortalarına doğru inşa edilen Bodrum Tepecik Camii (1756) inşa kitabesi ve mihrabının bordürlerinde "S" kıvrımlı dala sıralanmış zarif lâleler görülür (Fotoğraf 32-33). Koçarlı Cihanoğlu Mustafa Ağa Camii'ne 18. yüzyılın ikinci yarısındaki tamirlerde eklenmiş olması muhtemel minber ve vaaz kürsüsünde vazodan çıkan çiçekler

49 Anadolu'da Lâle Devri Mimarisi hakkında detaylı bilgi için bkz. Erkan Atak, Anadolu'da Lâle Devri Mimarisi (İstanbul Dışı Örnekler Üzerine Bir Araştırma), Basılmamış Doktora Tezi, Çanakkale Onsekiz Mart Üniversitesi Sosyal Bilimler Enstitüsü, 2014.

50 İlker Gümüş, Cihanoğlu Ailesine Ait Mimari Eserler, Basılmamış Yüksek Lisans Tezi, Yüzüncü Yıl Üniversitesi Sosyal Bilimler Enstitüsü, 2015, s.9697, r. 137-140. içerisinde lâle motifleri de bulunur. ${ }^{50}$ Yine benzer tarihlerde tamir ettirildiği kitabesinden anlaşılan İzmir Başdurak Camii (o.1774) mermer minberinde kıvrım dallar, yapraklar ve çiçeklerin arasına zarif lâleler işlenmiştir. ${ }^{51}$ III. Selim dönemi sadrazamlarından Yusuf Ziya Paşa'nın Erzurum valiliği esnasında 1797'de Keban'da yaptırdığı caminin mermer minberinde yan aynalıkların süslemeleri arasında vazodan çıkan lâle, gül ve karanfiller yer almaktadır. ${ }^{52}$ Üslup itibariyle yüzyılın ilk yarısını hatırlatan bu süslemeler, 18. asır içerisinde taşa işlenmiş son örnekler arasında yer almaktadır.
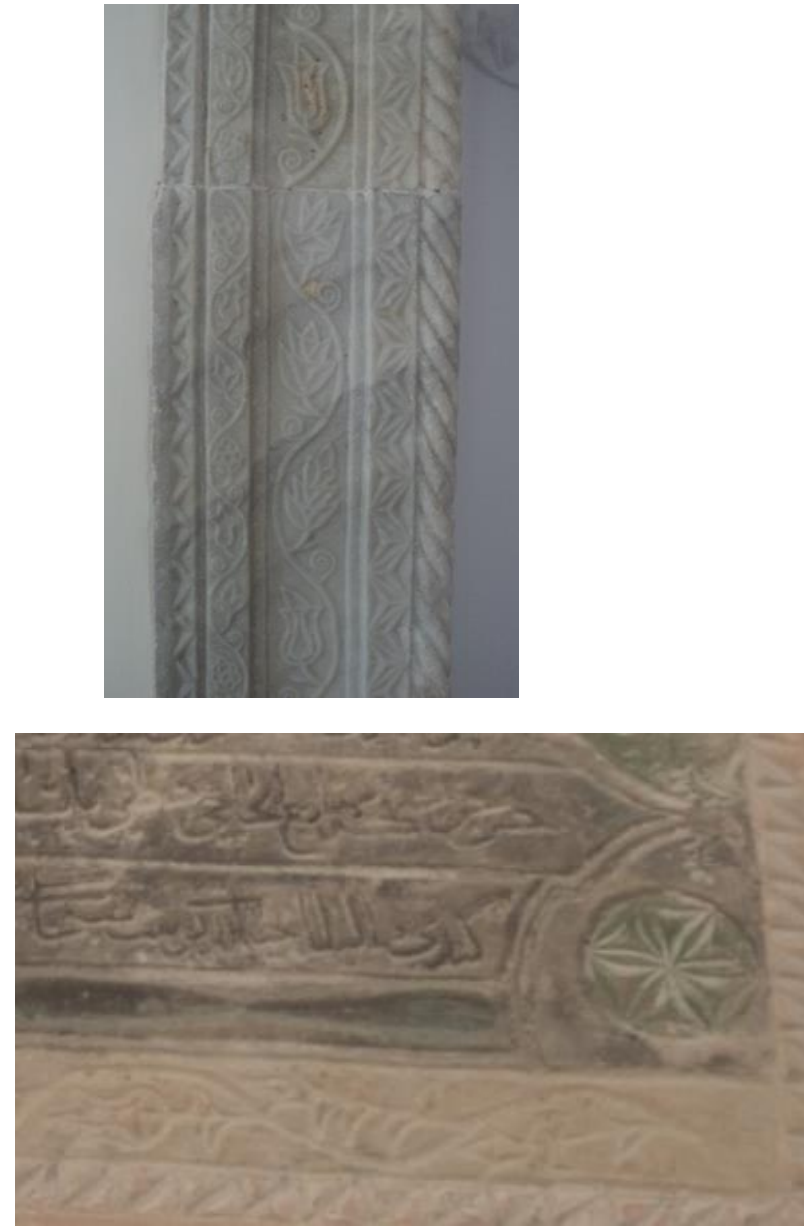

\section{Fotoğraf 32-33 : Bodrum Tepecik Camii Mihrap ve İnşa Kitabesi Taş Süsleme}

Yukarıda verilen örneklerden de anlaşılacağı üzere, gerek 18. yüzyıl öncesinde gerekse 18. yüzyıl içerisinde inşa edilen camilerin taş tezyînâtında lâle motifine hiç azımsanmayacak oranda yer verildiği anlaşılmaktadır. Elbette bu camilerin sayısını yapılacak yeni araştırmalarla artırabilmek mümkündür. Buna karşın elimizdeki mevcut örnekler lâlenin camilerin taş tezyînâtı içerisinde mihrap, minber, cümle kapısı ve kitabeler üzerinde yoğunlaştığını göstermektedir.

\section{Sonuç}

Türklerle birlikte Orta Asya bozkırlarından Anadolu'ya taşınan lâle çiçeği zaman içerisinde Türk kültür ve sanatının vazgeçilmez motiflerinden birisi olmuștur. Öyle ki lâle, sanatın her alanından kendine yer bulmuş nadir çiçek türlerinden birisidir. Süslemeye

${ }^{51}$ Sibel Polat, İzmir'deki Geç Dönem Osmanlı Camileri, Basılmamıș Yüksek Lisans Tezi, Selçuk Üniversitesi Sosyal Bilimler Enstitüsü, 2011, s.65-67

${ }^{52}$ Oktay Aslanapa, Osmanlı Devri Mimarîsi, İnkilâp Kitabevi, İstanbul, 2004, s.488. 
elverişli formu lâlenin farklı yüzeylerde ve malzemeler üzerine işlenmesine imkân sağlamıştır. Doğal haliyle ve islah edilmiş çeşitleriyle farklı renklerde yetişebilen lâlenin bu durumu ise özellikle kalemişi, çini ve kitap süslemeleri için oldukça elverişlidir. Zira lâlenin canlı renkleri, tasvir edildiği yüzeylere oldukça hareketli bir görünüm kazandırmaktadır. Bu nedenledir ki lâle söz konusu süsleme çeşitlerinde kimi zaman tek başına kimi zamansa bir kompozisyonun parçası olarak yaygın bir şekilde tasvir edilmiştir. Lâlenin bu denli yaygınlaşmasının bir diğer nedeni de sembolik anlamından ileri geliyor olmalıdır. Zira "lâle" kelimesindeki harflerin değiştirilmesiyle "Allah" yazılabilmekte ve ebced hesabıyla her iki kelime aynı değeri vermektedir.

Osmanlı Sanatı'na en erken giren çiçekler arasında yer alan lâlenin, 14. yüzyıldan itibaren farklı malzemeler üzerinde kendine yer bulduğu görülmektedir. 15 . yüzyll çini ve seramiklerinde stilize olarak karşımıza çıkan lâlenin kullanımı geçen yüzyıla göre artış göstermiştir.

16. yüzyılda kitap sanatları ve çini süslemelerde yaygınlaşan bu motifin taş tezyînâtta Lâle Devri öncesi kullanımına dair nispeten daha az örnek olsa da bunlar bir fikir üretebilmemize yardımcı olmaktadır. Söz konusu süslemelerin bazıları çoğunlukla Lâle Devri'yle başladığı kabul edilen üslubun aslında önceki yüzyılın ikinci yarısında da -sınırlı da olsa- denendiğini gösterir. Lâleye duyulan ilginin bir neticesi olarak 17. yüzyıl içerisinde çiçek ve lâle risâlelerinin artışı bu durumu desteklemektedir.

18. yüzyıla gelindiğinde lâlenin taş tezyînâtta kullanımda bir artış gözlemlenir. Çoğunlukla çeşme ve sebillerin süsleme programlarında farklı çiçeklerle birlikte natüralist bir üslupta işlenen lâle dönemin belirleyici motifi olmuştur. 18. yüzy1lın ilk çeyreğinde mevcut olan lâle risalelerinde isimleri geçen ve makbul kabul edilen bir takım lâle türlerinin bu süslemelere ilham kaynağı oldukları açıktır. Lâlenin camilerin taş tezyînâtında ise sivil yapılarla benzer bir anlayışla dönem üslubuna uygun olarak ele alındığı görülür. Dönemin önde gelen simalarının baniliğinde inşa edilen camilerde bu durum daha net izlenir. İstanbul'da Lâle Devri ve hemen sonrasına tarihlendirilen camilerde belirli bir ölçüde görülen bu süslemelerin yüzyılın ikinci yarısında etkisini yitirdiği gözlemlenir. Anadolu'da ise Damad İbrahim Paşa gibi dönemin saray bağlantılı bürokratları tarafından yaptırılan camilerde başkentteki üslupla eş zamanlı olarak lâlenin kendine yer bulduğu söylenebilir. Hattâ bazı camilerin süsleme programında İstanbul'daki çağdaş örneklerden daha zengin bir içeriğin olduğu görülür.

Neticede; Dünya üzerindeki en zarif çiçeklerden birisi olan lâle, Türk kültüründe ayrıcalıklı bir konuma sahiptir. Kimi zaman bir döneme ismini vermiş, kimi zaman bir üslubu şekillendirmiştir. Lâle Devri ile özdeşleştirilen bu çiçeğe olan ilginin daha önceki yüzyıllarda başladığı ve kronolojik bir düzenle gitgide artarak 17. yüzyıl içerisinde iyiden iyiye belirginleştiği söylenebilir. Bu durum sanat anlayışına da yansımış ve mimari tezyînâttan, kitap sanatlarına kadar sanatın farklı alanlarında lâlenin vazgeçilmez motiflerden birisi olmasına vesile olmuştur. Osmanlı Sanatı'nda 18. yüzyılın başlarından itibaren görülen üslup değişikliğinin ilk tohumlarının bir önceki yüzyılda atıldığını söylemek pek yanlış olmayacaktır. Yani Lâle Devri'nin lâlesi, bir önceki yüzyıldan miras kalmıştır. 


\section{KAYNAKÇA}

Ahmet Cevdet Paşa; Tarih-i Cevdet. 1, ( Haz. Mümin Çevik), Üçdal Neşriyat, İstanbul, 1972.

Aktepe, Münir; “Ahmed III”. İslam Ansiklopedisi. C.2. Ankara: Türkiye Diyanet Vakfı Yayınları, 1989, ss. 34-38.

Aktepe, Münir; “Damad İbrâhim Paşa Devrinde Lâle”. Tarih Dergisi 7, 1953, ss. 85-126.

Aktepe, Münir; "Damad İbrâhim Paşa Devrinde Lâle". Tarih Dergisi 9, 1954, ss. 23-38.

Aktepe, Münir; “Damad İbrâhim Paşa Devrinde Lâleye Dair Bir Vesika”, Türkiyat Mecmuası 11, 1954, ss. 115-130.

Altınay, Ahmet Refik; Lâle Devri, Tarih Vakfı Yurt Yayınları, İstanbul, 2011.

Aslanapa, Oktay; Osmanlı Devri Mimarîsi, İnkilâp Kitabevi, İstanbul, 2004.

Atak, Erkan; Anadolu Camilerinde Lâle Devri Üslubu, Gece Akademi, Ankara, 2019.

Atak, Erkan; “Osmanlı Mimarisinde Lâle Devri Üslûbu (Anadolu'daki Yansımalar)” Turkish Studies, Vol.13/10, 2018, ss.57-86.

Atak, Erkan; “Kayseri’de Bir Lâle Devri Eseri: Hasinli Camii”, Sosyal Bilimler Araştırmaları Dergisi, Cilt: 9, Sayı:2, 2014 , ss. 43-63.

Ayverdi, Ekrem Hakk1; 18. Asırda Lâle, (Haz. M. Uğur Derman), Kubbealtı Neşriyâtı, İstanbul, 2006.

Bağcı, Serpil vd.; Osmanlı Resim Sanatı, Kültür ve Turizm Bakanlığı Yayınları, İstanbul: 2006.

Bâkî; Bâkî Dîvânı, (Haz. Sabahattin Küçük), Kültür ve Turizm Bakanlığg Kültür Eserleri, Ankara, ty.

Baş, Gülsen; Diyarbakır'daki İslam Dönemi Mimarisinde Süsleme, Basılmamış Doktora Tezi, Yüzüncü Yıl Üniversitesi Sosyal Bilimler Enstitüsü, 2006.

Baytop, Turhan ve Cemal Kurnaz; "Lâle”, İslam Ansiklopedisi. C.27, Türkiye Diyanet Vakfı Yayınları, Ankara, 2003, ss. 79-81.

Bozkurt, Tolga; Osmanlı Selâtin Cami Mihrapları, Basılmamış Doktora Tezi, Selçuk Üniversitesi Sosyal Bilimler Enstitüsü, 2007.

Butasım, Nebi; Güneydoğu Anadolu Bölgesi’nde Osmanlı Dönemi Mihrapları (1515-1915), Basılmamış Doktora Tezi, Yüzüncü Yı1 Üniversitesi Sosyal Bilimler Enstitüsü, 2016.

Canca Erol, Gülçin; “Üsküdar Ahmediye Külliyesi ve Lâle Devri Mimarisi İçinde Bir Değerlendirme”, Üsküdar Sempozyumu VI 6-9 Kasım 2008, Üsküdar Belediyesi Yayınları, İstanbul, 2009, ss. 191-202.

Çakmakoğlu Kuru, Alev; “Orta Asya Türk Sanatında Palmet ve Lâle Motiflerinin Değerlendirmesi Hakkında Bir Deneme”, Belleten 230, 1997, ss. 37-54.

Çok, Beste; Isparta ve İlçeleri Camii Süslemeleri, Basılmamış Yüksek Lisans Tezi, Süleyman Demirel Üniversitesi Sosyal Bilimler Enstitüsü, 2010.

Çoruhlu, Yaşar; Erken Devir Türk Sanatı, Kabalcı Yayınları, İstanbul, 2007.

Dayıgil, Feyzullah; “İstanbul Çinilerinde Lâle”, Vakıflar Dergisi 1, 1938, ss. 83-90.

Dayıgil, Feyzullah; "İstanbul Çinilerinde Lâle”, Vakıflar Dergisi 2, 1942, ss. 223-232.

Dedeoğlu, Murat; Hatay Cami ve Mescitlerinde Taş Süsleme, Basılmamış Yüksek Lisans Tezi, Selçuk Üniversitesi Sosyal Bilimler Enstitüsü, 2018.

Demiriz, Yıldız; Osmanlı Mimarisinde Süsleme, Kültür Bakanlığı Yayınları, İstanbul, 1979.

Demiriz, Yıldız; Osmanlı Kitap Sanatında Natüralist Üslûpta Çiçekler, İstanbul Üniversitesi Edebiyat Fakültesi Yayınları, İstanbul, 1986.

Demiriz, Yıldız; "Sinan’ın Mimarisinde Bezeme”, Mimarbaşı Koca Sinan Yaşadı̆̆ı Çă̆ ve Eserleri, (Ed. Sadi Bayram), Vakıflar Genel Müdürlüğü Yayınları, İstanbul, 1988, ss. 465-474.

Denktaş, Mustafa; “Kayseri-Büyük Bürüngüz Köyü’ndeki Türk Anıtları”, Vakıflar Dergisi 27, 1998, ss. 161-190.

Dikmen, Hamit; Seyyid Vehbi ve Divanının Karşılaştırmalı Metni, Basılmamış Doktora Tezi, Ankara Üniversitesi Sosyal Bilimler Enstitüsü, 1991.

Diyarbekirli, Nejat; Hun Sanatı, Milli Eğitim Kültür Bakanlığı Yayınları, İstanbul, 1972.

Doğan, Tuncer; Gaziantep Türk-İslam Dönemi Mimari Süslemeleri, Basılmamış Doktora Tezi, Yüzüncü Yıl Üniversitesi Sosyal Bilimler Enstitüsü, 2013.

Dündar, Abdülkadir; “Özkent Türbeleri ve Minaresinin Türk İslâm Sanatları ve Mimarisindeki Yeri ve Önemi” Uluslararası Ali b. Osman elUş̧̂ิ Sempozyumu Bildirileri, (Ed. Ferhat Gökçe), Tika Yayınları, Bişkek, 2018, ss. 581-612. 
Goody, Jack; Çiçeklerin Kültürü, (Çev. Mehmet Beşikçi), Ayrıntı Yayınları, İstanbul, 2010.

Gümüş, İlker; Cihanoğlu Ailesine Ait Mimari Eserler, Basılmamış Yüksek Lisans Tezi, Yüzüncü Yıl Üniversitesi Sosyal Bilimler Enstitüsü, 2015.

Güzel, Gülnaz; Mardin'deki Osmanlı Dönemi Mimari Yapılarında Taş Süsleme, Basılmamış Yüksek Lisans Tezi, Yüzüncü Yıl Üniversitesi Sosyal Bilimler Enstitüsü, 2010.

Kahraman, Seyit Ali; Osmanlı Çiçekleri ve Çiçekçileri, Lale Yayınları, İstanbul, 2014.

Kartal, Ahmet; Klâsik Şiirinde Lâle, Akçağ Yayınları, Ankara, 1998.

Mevlânâ Celâleddîn-i Rûmî; Dîvân-ı Kebîr, (Haz. Abdülbâki Gölpınarlı), Remzi Kitapevi, İstanbul, 1957.

Mülayim, Selçuk; "Selçuklu Palmet Motiflerinin Tipolojisi”, Anadolu (Anatolia), 20, 1976, ss. 141-153.

Nedîm; Nedim Divanı, (Haz. Abdülbâki Gölpınarl1), İnkilâp Kitabevi, İstanbul, 1951.

Oral, Bülent; Mimar Koca Sinan ’ın İstanbul'daki Camilerinde Minber, Basılmamış Doktora Tezi, Gazi Üniversitesi Sosyal Bilimler Enstitüsü, 2014.

Ögel, Bahaeddin; İslamiyet Öncesi Türk Kültür Tarihi, Türk Tarih Kurumu Basımevi, Ankara, 1984.

Özbek, Yıldıray; Erken Osmanlı Mimarisinde Taş Süsleme, Doktora Tezi, Hacettepe Üniversitesi Sosyal Bilimler Enstitüsü, 1999.

Özcan Biçer, Şehnaz; Uygur Yazmalarında Sayfa Düzeni, Basılmamış Doktora Tezi, Marmara Üniversitesi Türkiyat Araştırmaları Enstitüsü, 2010.

Öztuna, Yılmaz; Başlangıcından Zamanımıza Kadar Büyük Türkiye Tarihi 6, Ötügen Yayınevi, İstanbul, 1978.

Polat, Sibel; İzmir'deki Geç Dönem Osmanlı Camileri, Basılmamış Yüksek Lisans Tezi, Selçuk Üniversitesi Sosyal Bilimler Enstitüsü, 2011.

Râşid Mehmed Efendi ve Çelebizâde İsmaîl Âsım Efendi; Târîh-i Râşid ve Zeyli 3, (Haz: Abdülkadir Özcan vd.), Klasik Yayınları, İstanbul, 2013.

Söylemez, Duygu İlkhan; Batılılaşma Dönemi İstanbul Cami Cephelerinde Taş Süsleme (1703-1839), Basılmamış Doktora Tezi, Selçuk Üniversitesi Sosyal Bilimler Enstitüsü, 2010.

Şeyhî; Şeyhî Dîvânı, (Haz. Halit Biltekin), Kültür ve Turizm Bakanlığı Kültür Eserleri, Ankara, 2018.

Uysal, Ali Osman; “Bolvadin'de Bir Lâle Devri Eseri: Ağılönü Çeşmesi” Ankara Üniversitesi Dil ve Tarih-Coğrafya Fakültesi Dergisi, Cilt 32 (1-2), 1988, ss.33-55.

Uysal, Zekiye; “Topkapı Sarayındaki III. Ahmet Kütüphanesi’nin Alçı Süslemeleri”, Çanakkale Araştırmaları Türk Yıllı̆̆g, Say1: 26, 2019, ss. 331-376.

Ünver, Süheyl; “Türkiye’’de Lâle Tarihi”, Vakıflar Dergisi, 9, 1974, ss. 265-276.

Yenişehirlioğlu, Filiz; “Tekfur Sarayı Çinileri ve Eyüp Çömlekçiliği”, Anadolu'da Türk Devri Çini ve Seramik Sanatı, (Ed: Gönül Öney-Zehra Çobanlı), Kültür ve Turizm Bakanlığı Yayınları, İstanbul, 2007, ss. 349-364.

Yetkin, Şerare; Anadolu'da Türk Çini Sanatının Gelişmesi, İstanbul Üniversitesi Edebiyat Fakültesi Yayınları, İstanbul, 1972.

http://www.mustafacambaz.com/details.php?image id=12844 